\title{
Curfew Laws, Freedom of Movement, and the Rights of Juveniles
}

Benjamin C. Sasse

Follow this and additional works at: https://scholarlycommons.law.case.edu/caselrev

Part of the Law Commons

\section{Recommended Citation}

Benjamin C. Sasse, Curfew Laws, Freedom of Movement, and the Rights of Juveniles, 50 Case W. Rsrv. L. Rev. 681 (2000)

Available at: https://scholarlycommons.law.case.edu/caselrev/vol50/iss3/7

This Note is brought to you for free and open access by the Student Journals at Case Western Reserve University School of Law Scholarly Commons. It has been accepted for inclusion in Case Western Reserve Law Review by an authorized administrator of Case Western Reserve University School of Law Scholarly Commons. 


\section{CURFEW LAWS, FREEDOM OF MOVEMENT, AND THE RIGHTS OF JUVENILES}

\section{INTRODUCTION}

In the early 1990s, the arrest rate for minors between the ages of ten and seventeen in the District of Columbia was the highest in the nation. ${ }^{1}$ Teens from the age of fifteen to nineteen met violent deaths in Washington D.C. more frequently than in any other city in the nation. ${ }^{2}$ Moreover, the problem was escalating. Between 1987 and 1995, the juvenile arrest rate "for aggravated assault increased by $89.8 \%$, for murder by $157 \%$, and for carrying a dangerous weapon by $282.7 \%$."3

Concerned with these frightening statistics, the D.C. Council adopted a juvenile curfew ordinance. ${ }^{4}$ Washington, D.C. was not the first city to do so. President Clinton advocated curfew laws as a measure to keep children safe, ${ }^{5}$ and during the 1990 s many cities have turned to curfew laws ${ }^{6}$ in an effort to stem rising rates in juvenile crime. $^{7}$

Litigation ensued, and the District of Columbia's curfew law began its journey through the federal judicial system. In Hutchins v.

1 See Hutchins v. District of Columbia, 188 F.3d 531, 542 (D.C. Cir. 1999) (en banc) ("[T]he juvenile violent crime arrest rate for juveniles ages 10 to 17 was higher than that in any state and was more than three times the national average.") (citation omitted).

2 See id.

3 Hutchins v. District of Columbia, 144 F.3d 798, 810 (D.C. Cir. 1998), rev'd on reh'g en banc, 188 F.3d 531 (D.C. Cir. 1999).

4 See infra note 278 and accompanying text.

5 See The White House, MaKIng OUR Schools ANd Communities SAFER (March 19, 1998) ("Because of the success of curfews in helping to fight juvenile crime and keeping children safe, the Clinton Administration has encouraged communities to adopt curfew policies.").

6 See Mark Potok, Teen curfews 'the norm' in more cities, USA TODAY, June 26, 1995, at $1 \mathrm{~A}$ (stating that since 1990 " 53 cities have enacted a curfew ordinance; another 37 revised older laws").

7 See id. at $1 \mathrm{~A}$ ("The most common age for arrestees nationally is now 16, and an upcoming Department of Justice analysis reports that juveniles were behind $30 \%$ of the growth in violent crime between 1988 and 1992."); Patty Ryan, Lights on, teens home, THE TAMPA TRIB., July 16, 1995, at 1 ("Nationwide, arrests for juvenile violent crime shot up 67 percent in the nine years after 1984.”). 
District of Columbia, ${ }^{8}$ the district court found the curfew unconstitutional on the ground that it impermissibly burdened minors' right to freedom of movement and interfered with a parent's right to control the activities of their children. ${ }^{9}$ On appeal, a three-judge panel affirmed without agreeing on a rationale. ${ }^{10}$ The D.C. Circuit agreed to rehear the case en banc and reversed, again unable to agree upon a rationale."

This Note focuses on the central constitutional question posed by juvenile curfew laws and confronted by the D.C. Circuit Court of Appeals: whether a curfew violates a minor's ${ }^{12}$ right to travel on public fora. ${ }^{13}$ The question of whether a curfew law violates a minor's right to travel on public fora encompasses two issues: (1) whether a right to

\footnotetext{
8942 F. Supp. 665,680 (D.D.C. 1996), rev'd on reh'g en banc, 188 F.3d 531 (D.C. Cir. 1999).

9 See id. at 680.

10 Judge Rogers, writing for the court, argued that minors possess fundamental rights, but
} legislation burdening these rights should be subject to an intermediate standard of review. See Hutchins v. District of Columbia, 144 F.3d 798, 809-10 (D.C. Cir. 1998), rev'd on reh'g en banc, 188 F.3d 531 (D.C. Cir. 1999). Judge Tatel, on the other hand, argued that legislation burdening the rights of minors should be subject to a strict scrutiny standard of review. See id. at 826 (Tatel, J., concurring). Judge Silberman, in contrast, argued that minors have no fundamental right "to be unaccompanied on the streets at night." Id. at 828 (Silberman, J., dissenting).

11 The plurality opinion in Hutchins held that: (1) juveniles do not have a fundamental right to be on the streets at night without adult supervision; (2) parents do not have a right to "unilaterally determine" if their children will roam the streets at night; and (3) even assuming that the curfew implicates the fundamental rights of both minors and aduits, the curfew satisfies intermediate scrutiny. Hutchins, 188 F.3d at 538-48. Judge Edwards, concurring in part and concurring in result, found that the curfew law implicates the fundamental right of parents to control the "'care,' 'nurture,' 'upbringing,' 'management,' and 'rearing"' of their child, id. at 560 , but the law survives intermediate scrutiny. See id. at 548-52. In contrast, Judges Wald and Garland, concurring in part and concurring in result, found that although the curfew law implicates the fundamental rights of both minors and parents, but in both instances survives intermediate scrutiny. See id. at 552. Judge Rogers, concurring in part and dissenting in part, found that the curfew law implicates a minor's fundamental right "to walk through public streets without thereby subjecting oneself to police custody," id. at 562, that intermediate scrutiny is the appropriate standard of review, and that the curfew law is unconstitutional under an intermediate scrutiny standard. See id. at 563-70. Judge Tatel, dissenting, found that the curfew law burdens the fundamental rights of both minors and parents, that in each case legislation that burdens those rights should be subject to strict scrutiny, and that the curfew law cannot survive strict scrutiny because of the burdens it places on parental rights. See id. at 562-70.

12 Throughout the course of this Note, I will use the terms "juveniles," "minor," and "child" interchangeably to refer to those unemancipated persons who are under the age of 17.

13 Many other constitutional challenges have been made against curfew laws, but they are beyond the scope of this Note. Among these challenges are: vagueness, freedom of movement, freedom of speech, freedom of association, freedom of assembly, and the Equal Protection Clause. See Bykofsky v. Borough of Middletown, 401 F. Supp. 1242, 1248 (M.D. Pa. 1975), aff'd, 535 F.2d 1245 (3d Cir. 1976) (holding that a curfew ordinance did not infringe on freedom of speech). These laws have also been challenged under the Fourth Amendment, and for violating a parent's right to freedom from undue government interference upon child rearing. See, e.g., Schleifer v. City of Charlottesville, 963 F. Supp. 534, 538 (W.D. Va. 1997) (applying a rational basis test to uphold a curfew law against an undue influence claim because age is not a suspect class). 
free movement exists; and (2) if such a right exists, does it protect juveniles to the same extent that it protects adults.

Part I of this Note considers whether a right to travel on public fora may be established by analogy to Supreme Court case law on the right to interstate travel. Part II sketches the struggle of the Supreme Court to find a standard of review for alleged burdens of juvenile rights. Part III analyzes the circuit split on the issue of intrastate travel and concludes that a right to travel on public fora exists as an aspect of substantive due process. Part III also concludes that courts confronting this issue should use an "undue burden" standard as a threshold inquiry when deciding whether to apply heightened scrutiny to alleged violations of this right. Part IV analyzes the three standards of review (strict scrutiny, intermediate review, and rational basis) that have been used by courts in dealing with juvenile rights and concludes that alleged infringements of rights held by juveniles that would be fundamental if held by adults merit intermediate scrutiny. Finally, Part V of this Note applies the "undue burden" test and the intermediate scrutiny standard of review to the District of Columbia curfew ordinance, and concludes that it is constitutional.

\section{THE Right TO INTERSTATE TRAVEL}

"Once the right to travel is curtailed, all other rights suffer ...."

Courts frequently rely on interstate travel case law to support the proposition that a fundamental right to intrastate travel exists. ${ }^{15}$ Little in the way of argument, however, is offered to support this conclusion. Stating that "language in the decisions suggests that the right extends to purely local movement"16 does not help the cause. A meaningful argument supporting this statement must identify both the source of such a right and the rationale underlying its existence. ${ }^{17}$

14 Aptheker v. Secretary of State, 378 U.S. 500, 520 (1964) (Douglas, J., concurring).

15 See, e.g., Schleifer v. City of Charlottesville, 963 F. Supp. 534, 542-43 (W.D. Va. 1997), affd, 159 F.3d 843 (4th Cir. 1998) (relying in part on interstate travel case law); Bykofsky v. Borough of Middletown, 401 F. Supp. 1242, 1254-55 (M.D. Pa. 1975), aff'd mem., 535 F.2d 1245 (3d Cir. 1976) (citing, inter alia, right to interstate travel cases).

${ }_{16}$ Hutchins, 188 F.3d at 561 (Rogers, J,, concurring in part and dissenting in part).

17 Thus, Judge Rogers is wrong when he argues in dissent that "there is no reason for this court to resolve the debate" about the source of the right to travel. Id. at $562 \mathrm{n} .22$. This would be true if the court was merely applying Supreme Court precedent, which it is not. Instead, Judge Rogers' opinion attempts to analogize interstate travel case law to an intrastate travel case. Claiming that the right to travel encompasses both rights, see id. at 560-62, the opinion makes a sweeping generalization that interstate and intrastate travel are the same without offering a reason why this is so-the logical fallacy of dicto simpliciter. Nor does the assertion that intrastate mobility is "important" because of "its utility and the implications of its denial," id. at 561, aid the argument. Despite its emotive appeal, this statement is irrelevant to the argument that a right of intrastate mobility is implied by the Supreme Court's interstate travel case law. 
One of the problems with relying on interstate travel cases is the inability of the Court to agree upon a constitutional source for this right. Not surprisingly, the source of such a right (as well as its scope as developed in these cases) has clear implications for the viability of a right to travel on public fora by analogy. This Part reviews the various constitutional theories the Court has offered to support its interstate travel case law. It also assesses the prospects of each of these theories to serve as a springboard for an analogous right to travel on public fora.

The pedigree of the right to interstate travel is long and varied. The right to interstate travel first appeared in 1825 as an aspect of the privileges enjoyed by citizens of the United States under the Article IV Privileges and Immunities Clause. ${ }^{18}$ Since this first mention, the right to travel has been variously described as residing within the ambit of the Commerce Clause, the Fourteenth Amendment Privileges or Immunities Clause, and as a right inferred from the structure of our Constitution. ${ }^{19}$ In more recent years, this right has also been found to reside in the Due Process Clause.$^{20}$ However, on the whole, the Court has agreed to disagree on the specific source of this right. ${ }^{21}$

\section{A. Article IV Privileges and Immunities Clause}

Case law grounding the right to travel in the Article IV Privileges and Immunities Clause is rooted in 19th century case law. ${ }^{22}$ In Corfield v. Coryell, ${ }^{23}$ Justice Washington, while riding circuit, inti-

is See Corfield v. Coryell, 6 F. Cas. 546, 552 (C.C.E.D. Pa. 1823) (stating that the right of a citizen to pass through another state was protected by the Article IV Privileges and Immunities Clause).

${ }_{19}$ See Attomey General of New York v. Soto-Lopez, 476 U.S. 898, 902 (1986); Lutz v. City of York, 899 F.2d 255, 262-65 (3d Cir. 1990).

20 See, e.g., Kent v. Dulles, 357 U.S. 116, 125 (1958) ("The right to travel is a part of the 'liberty' of which the citizen cannot be deprived without due process of law under the Fifth Amendment.").

${ }_{21}$ See Soto-Lopez, 476 U.S. at 902 ("[]nn light of the unquestioned historic acceptance of the principle of free interstate migration ... we have not felt impelled to locate this right definitively in any particular constitutional provision.") (citation omitted).

${ }_{22}$ See, e.g., Corfield v. Coryell, 6 F. Cas. 546, 552 (C.C.E.D. Pa. 1823). But see Saenz v. Roe, 119 S. Ct. 1518 (1999). Saenz separates the "right to travel" into three components: (1) the right of a citizen to enter into another state; (2) the right of that citizen to be treated as a "welcome visitor" while in another state; and (3) if the citizen chooses to become a permanent resident of the state which they are visiting, the right to be treated like all other citizens of that state. See id. at 1525. The court did not identify the source of the first component of the right to travel. See id. The court held that the second component is "expressly protected" by the Article IV Privileges and Immunities Clause, while the third is governed by the Privileges or Immunities Clause of the Fourteenth Amendment. See id. at 1526.

${ }^{23} 6$ F. Cas. 546 (C.C.E.D. Pa. 1823). The Corfield court held that a New Jersey statute, which prohibited non-residents from gathering shellfish within New Jersey's waters in a ship that was owned by a non-resident, was constitutional. See id. at 551-53. 
mated that this clause was a source of fundamental rights. ${ }^{24}$ Justice Washington broadly described these rights as those necessary for "the enjoyment of life and liberty,", and included "[t] of one state to pass through . . . any other state.",26

This conception of the Article IV Privileges and Immunities Clause lasted for less than fifty years. In Paul v. Virginia, ${ }^{27}$ the Court held that a corporate tax imposed by Virginia on foreign insurance companies was constitutional. ${ }^{28}$ The Paul Court rejected the Corfield view that the Article IV Privileges and Immunities Clause was a source of implied fundamental rights in dicta. ${ }^{29}$ The effect of the Paul dicta was to redefine the right to interstate travel as an antidiscrimination right embodied in principles of federalism. ${ }^{30}$

The Court embraced the Paul dicta in Bray v. Alexandria Women's Health Clinic. ${ }^{31}$ Citing Paul, the Court observed that the right to interstate travel is protected against two types of obstacles: (1) "the erection of actual barriers to interstate movement;" "32 and (2) "'being treated differently' from intrastate travelers." ${ }^{33}$ This formulation of the right to interstate travel is fully consistent with the antidiscrimination principle set forth in Paul.

24 See id. at 551. ("We feel no hesitation in confining these expressions to those privileges and immunities which are, in their nature, fundamental; which belong, of right, to the citizens of all free governments ....").

${ }^{25}$ Id.

${ }^{26}$ Id. at 552. In total, Corfield"s definition of fundamental rights includes "everything but the kitchen sink." JOHN HART ELY, DEMOCRACY AND DISTRUST 198 n.64 (1980).

2775 U.S. (8 Wall.) 168 (1868).

28 See id. at 177.

29 See id. at 180 ("[T]he privileges and immunities secured to citizens of each State in the several States ... . are those privileges and immunities which are common to the citizens in the latter States under their constitution and laws by virtue of their being citizens."). In Paul, a man serving as an agent for an unlicensed corporation was indicted for violating a statute that forbade anyone from acting as an agent without a license. See id. at 169. A tax had to be paid in order to obtain a license. See id. The agent argued that the act violated the Article IV Privileges and Immunities Clause and the Commerce Clause. See id. at 170-72. The Court held that the Article IV Privileges and Immunities Clause did not apply because the corporation was not a citizen within the meaning of that clause. See id. at 177. Therefore, any discussion of the substantive scope of the rights conferred by that clause was pure dictum.

30 See Lutz v. City of York, 899 F.2d 255, 262 (3d Cir. 1990) (recognizing the Article IV Privileges and Immunities clause as "a federalism-based antidiscrimination principle").

31506 U.S. 263 (1993). Abortion clinics and organizations supporting those clinics sued to enjoin Operation Rescue from demonstrating in a manner that obstructed general access to those clinics. See id at 266 . The District Court granted injunctive relief under 42 U.S.C. $\$ 1985$ (3) (1992), whose ancestor was $\S 2$ of the Civil Rights Act of 1871. See id. The precise issue before the Court was whether a federal cause of action had been stated by the alleged private conspiracy conducted by Operation Rescue to deprive individuals of their right to interstate travel and their right to an abortion. See id. at 268, 274, 277.

32 Id. at 277 (quoting Zobel v. Williams, 457 U.S. 55, 60 n.6 (1982) and citing Paul, 75 U.S. ( 8 Wall.) at 180$)$.

33 Id. (quoting Zobel, 457 U.S. at 60 n.6 and citing Paul, 75 U.S. (8 Wall.) at 180). 
There are two difficulties with applying by analogy the Article IV Privileges and Immunities Clause to the right to travel on public fora. First, language of the clause itself will not support a right to travel on public fora. The text of Article IV, Section Two of the Constitution states that "[t]he Citizens of each State shall be entitled to all Privileges and Immunities of Citizens in the several States." ${ }^{34}$ As Professor Ely notes, "[t]his [is] an equality provision, intended to keep states from treating outsiders worse than their own citizens. ${ }^{35}$ The clause does not speak to the duties owed by states to their own citizens. Therefore, the Privileges and Immunities Clause cannot be the source of any right to intrastate travel.

The second problem with trying to locate a right to travel on public fora under the Privileges and Immunities Clause is that the clause would have no security. As Paul made clear, this clause is violated only where a state denies to visitors the privileges that it bestows upon its own citizens. ${ }^{36}$ If all citizens are treated equally, then the clause is not violated. Thus, a state could withhold the right to travel from both its own citizens and out-of-state visitors and still comply with Paul.

\section{B. The Commerce Clause}

The view that the right to travel is an aspect of the Commerce Clause originates in Edwards v. California. ${ }^{37}$ Edwards involved a California penal statute that forbade a resident from knowingly aiding a nonresident in entering the state..$^{38}$ The Court relied on the Commerce Clause to strike down the statute, stating that "it is settled beyond question that the transportation of persons is 'commerce,' within the meaning of [the Commerce Clause]. ${ }^{39}$ Thus, the question was whether a protectionist measure, designed to keep indigent nonresidents out of the state, violated the negative aspect of the Com-

34 U.S. CONST, art. IV, \$ 2.

35 ELY, supra note 26, at 23.

36 See Paul, 75 U.S. (8 Wall.) 176-77.

37314 U.S. 160 (1941).

${ }^{38}$ See id. at 165-66.

39 Id. at 172 (citations omitted). 
merce Clause. ${ }^{40}$ Viewed from this perspective, the Court concluded without much difficulty that the statute was unconstitutional. ${ }^{41}$

Any attempt to apply the Commerce Clause right to interstate travel rationale by analogy to an asserted right to travel on public fora must fail. The "negative," or "dormant," Commerce Clause prevents a state from enacting protective legislation. ${ }^{42}$ There are several problems, however, with analyzing intrastate travel restrictions such as curfew laws under such a doctrine. First, as the Court recognized in Bray, if the right to interstate travel is derived from the negative Commerce Clause, then "it could be eliminated by Congress." ${ }^{\text {"43 }} \mathrm{Sec}-$ ond, a curfew law applies generally to both in-state and out-of-state residents. ${ }^{44}$ Therefore, there is no protectionist motive on the part of the state or municipality in enacting a curfew law.

Third, applying the dormant Commerce Clause to right to travel on public fora cases would skew the analysis of the courts by focusing on the wrong questions. People who oppose curfew laws do so because they don't like their travel restricted, not because Joe Oklahoma is upset that Tom Nebraska's business is benefiting from the regulation. Thus, application of the dormant Commerce Clause would skew the terms of the debate.

\section{National Citizenship}

In a concurring opinion in Edwards v. California, ${ }^{45}$ Justice Douglas described the right to interstate travel as "an incident of national citizenship."46 The Court has occasionally grounded the right to travel in a concept of national citizenship not tied to any specific constitutional provision. The first member of the Court to do so was

40 As the Edwards Court stated, "[t]he issue presented in this case, therefore, is whether the prohibition embodied in [the statute] against the 'bringing' or transportation of indigent persons into California is within the police power of that State. We think that it is not, and hold that it is an unconstitutional barrier to interstate commerce." Id at 173; see also Lutz v. City of York, 899 F.2d 255, 265 (3d Cir. 1990) ("Edwards . . . involved a statute prohibiting the importation of 'goods' perceived to produce unwanted local burdens .... . [T] his is virtually per se unconstitutional.").

4t See Edwards, 314 U.S. at 174 ("We think this statute must fail under any known test of the validity of State interference with interstate commerce.").

42 See City of Philadelphia v. New Jersey, 437 U.S. 617, 624 (1978) (stating that the crucial issue under the dormant Commerce Clause is whether a law "is basically a protectionist measure, or whether it can fairly be viewed as a law directed to legitimate local concerns").

43 Bray v. Alexandria Women's Health Clinic, 506 U.S. 263, 277 n.7 (1993).

44 In fact, many current curfew laws provide an exception for interstate travel. See, e.g., Dallas, Tex., Rev. ORdinanCES ch. 31, § 31-33(c)(1)(C) (1992); see also infra note 278 (setting out the terms of the District of Columbia curfew ordinance).

45 314 U.S. 160 (1941).

46 Id. at 178 (Douglas, J., concurring) (emphasis in original). Justice Douglas believed that the right to interstate travel was firmly established as a right of national citizenship prior to the adoption of the Fourteenth Amendment. See id. at 179. 
Chief Justice Taney in his dissenting opinion in the Passenger Cases. ${ }^{47}$ Chief Justice Taney stated that "[w]e are all citizens of the United States; and, as members of the same community, must have the right to pass and repass through every part of if without interruption, as freely as in our own States." ${ }^{, 48}$

Chief Justice Taney's statement is a conclusion, not a constitutional argument. The Chief Justice did not make reference to anything in the text, structure, or history of the Constitution that suggests that a right to interstate travel exists. The Court bolstered Chief Justice Taney's statement in Shapiro v. Thompson. ${ }^{49}$ Shapiro explained that the right to interstate travel results from the unity of "the nature of our Federal Union and our constitutional concepts of personal liberty." This unity is not present when the issue is whether there is a right to travel on public fora.

The right to interstate travel recognized in Shapiro exists, in part, to prevent one state from excluding (or expelling) citizens of other states. Language in later decisions confirms that this was the purpose of the right to travel recognized in Shapiro. In fact, the right recognized by Shapiro is now described "more precisely, [as] the right of free interstate migration." ${ }^{51}$ The "nature of our Federal Union" requires that citizens of the United States, as citizens of the United States, be free to relocate from one state to another if they so choose.

The right to travel on public fora does not implicate the "nature of our Federal Union." Intrastate travel restrictions do not prevent citizens from changing residences or implicate any other federalismrelated concerns. By definition, these travel restrictions apply solely to travel within the state that enacted the legislation. Thus, there is no "unity" of interests between the "nature of our Federal Union" and constitutional concepts of individual liberty in an interstate travel case. Therefore, the right to interstate travel recognized by concepts of "national citizenship" provides a poor analogy for a right to travel on public fora.

\section{Substantive Due Process}

Kent $v$. Dulles ${ }^{52}$ described the right to travel as "a part of the 'liberty' of which the citizen cannot be deprived without due process

\footnotetext{
4748 U.S. (7 How.) 283 (1849).

48 Id. at 492 (Taney, C.J., dissenting).

49394 U.S. 618 (1969).

50 Id. at 629 .

51 Attomey General of New York v. Soto-Lopez, 476 U.S. 898, 902 (1986).

52357 U.S. 116 (1958).
} 


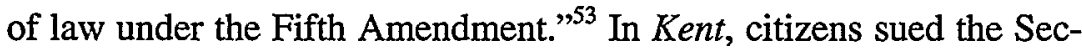
retary of State after he refused to issue them passports. ${ }^{54}$ Hence, the right to travel involved in Kent was the right to travel internationally. The Court held that the Secretary of State's action in denying passports on the basis of association was beyond the authority vested in the Secretary by Congress under the Immigration and Nationality Act of $1952 .{ }^{55}$ Thus, Kent avoided the "important constitutional question[]" that would arise if Congress had authorized a restriction of "the citizens' right of free movement." 36

Much of the discussion in Kent surrounding the right to travel concerned the social utility of visiting foreign nations. ${ }^{57}$ Kent also cited the writings of scholar Zachariah Chafee extensively to reference both the right to migrate from one state to another and the right to travel abroad. ${ }^{58}$ The citations, and other language in the opinion, suggest that the Court was analogizing the right to travel internationally to the right to travel interstate. ${ }^{59}$

The discussion of the right to travel offered in Kent, however, was dictum because the Court avoided the constitutional question by a narrow interpretation of the Immigration and Nationality Act of 1952. The Court returned to the Kent dicta in Haig v. Agee $e^{60}$ and settled on a curious interpretation. Agee concerned an action brought by an ex-CIA agent challenging the revocation of his passport by the Secretary of State. ${ }^{61}$ Agee argued that the act of revoking his passport impermissibly burdened his right to travel freely abroad. ${ }^{62}$ The Court disagreed, stating that "the freedom to travel outside the United States must be distinguished from the right to travel within the United States." 63

53 Id. at 125 .

54 The Secretary of State refused to issue the passports because the plaintiffs would not file an affidavit concerning their alleged Communist party membership. See id. at 119-20.

s5 See id. at 130.

56 Id.

57 See id. at 126. The Court emphasized that this right emerged in Anglo-Saxon law at the time of the Magna Charta. See id. (citing ZaCHARIAH CHAFEE, THREE HUMAN RIGHTS IN THE CONSTITUTION OF 1787 (1st ed. 1936)).

58 See id. (citing CHAFEE, supra note 57, at 171-81, 197).

59 See $i d$. The Court stated that "[f]reedom of movement across frontiers in either direction, and inside frontiers as well, was a part of our heritage. Travel abroad, like travel within the country, may be necessary for a livelihood." Id. Read in context, these sentences compare the right to interstate travel with the right to travel abroad.
453 U.S. 280 (1981).
61 See id. at 283-87.
62 See id. at 306.
63 Id. (emphasis in original). 
Why these two rights must be distinguished is not entirely clear. Agee quoted from Califano v. Aznavorian, ${ }^{64}$ wherein the Court recognized "the crucial difference between the freedom to travel internationally and the right of interstate travel. ${ }^{265}$ Califano explained that the right to interstate travel is "virtually unqualified," whereas the right to travel abroad is "no more than an aspect of the 'liberty' protected by the Due Process Clause of the Fifth Amendment. ${ }^{.66}$ Yet, this statement is nothing more than a conclusion, and Agee offers no explanation as to why this is true. The only hint of a rationale for this disparate treatment comes from Califano, wherein the Court emphasized that, unlike the right to travel abroad, the right to interstate travel has been "recognized by this Court for over 100 years."

If longevity (in terms of the number of years that a right is recognized by the Court) is the sole criterion for determining whether a right to travel is fundamental, then the right to travel on public fora is in trouble. The Court has never explicitly recognized this right. Just last term in City of Chicago v. Morales, ${ }^{68}$ the Court declined to address the issue of whether such a fundamental right exists. ${ }^{69}$ At the very least, Agee and Morales suggest that the Court is unwilling to extend the right to travel without some sort of independent justification explaining why the specific right asserted is fundamental. ${ }^{70}$

In sum, the Court's interstate travel decisions do not lend themselves to an easy analogy to the right to travel on public fora. Most of the decisions ascribe the right to interstate travel to a source that will not support such an analogy. While the Due Process Clause will support such an analogy, the tenor of the Court's opinions suggests that it will not recognize such a right without some sort of independent justification. Therefore, relying on interstate travel case law, without more, to support a right to travel on public fora is inappropriate.

64439 U.S. 170 (1978).

6s Id. at 176.

66 Id. (quoting Califano v. Torres, 435 U.S. 1, 4 n.6 (1953)).

67 Id. (citations omitted).

6s 119 S. Ct. 1849 (1999).

69 See id. at 1863 n.35 (basing decision on the statute being overbroad and therefore holding that "it is unnecessary to reach the question whether the ... ordinance is invalid as a deprivation of substantive due process").

${ }^{70}$ Such a justification is explored later in this Note. See infra Part III (discussing the right to travel on public fora). 


\section{THE DEVELOPMENT OF JUVENILE RightS}

\section{"Those who are still in a state to require being taken care of by others must be protected against their own actions as well as against external injury." 71}

The scope of juvenile rights under our Constitution remains uncertain to this day. ${ }^{72}$ The rights of minors got off to an inauspicious start in this century, ${ }^{73}$ but picked up steam during the Warren Court years. ${ }^{74}$ However, despite occasional broad pronouncements, ${ }^{75}$ the treatment of minors remains variable and uncertain. ${ }^{76}$ Perhaps the best way to bring order to these decisions is to separate those that deal with procedure from those that deal with substantive liberty interests.

\section{A. Juvenile Rights and Procedural Due Process}

Starting with In re Gault, ${ }^{77}$ the Court wrote a series of decisions that were designed to reform the juvenile system. However, the crossover relevance of these decisions to the substantive liberty interests of minors is probably minimal. These cases focused on the nature of the juvenile court system and its deficiencies, not the liberation of minors.

In re Gault held that the rights to notice of charges, counsel, and confrontation of accusers, as well as the right against compulsory self-incrimination and the right to cross-examine witnesses, apply to minors. ${ }^{78}$ The Court emphasized the importance of the procedural safeguards required by the Due Process Clause, commenting that "these instruments ... enhance the possibility that truth will emerge from the confrontation of opposing versions and conflicting data.,79

71 J. Mill, ON LIBERTY 69 (Penguin Classics ed. 1974).

72 As Justice Marshall states in Bykofsky v. Borough of Middletown, 429 U.S. 964 (1976), "[t]he question squarely presented by this case ... is whether the due process rights of juveniles are entitled to lesser protection than those of adults. The prior decisions of this Court provide no clear answer." Id. at 965 (Marshall, J., dissenting) (footnote omitted).

${ }_{3}$ See, e.g., Pierce v. Society of Sisters, 268 U.S. 510, 534 (1925) ("No question is raised concerning the power of the State ... to require that all children of proper age attend some school ....").

${ }^{4}$ See, e.g., Tinker v. Des Moines Indep. Community School Dist., 393 U.S. 503, 511 (1969) (holding that "[s]chool officials do not possess absolute authority over their students. Students in school as well as out of school are 'persons' under our Constitution.").

75 See id. (stating that students "are possessed of fundamental rights which the State must respect").

76 See Bykofsky, 429 U.S. at 965 (Marshall, J., dissenting) (stating that "[t]he prior decisions of this court provide no clear answer" to the question of whether the due process rights of minors are entitled to lesser protection than those of adults).

7387 U.S. 1 (1967).

78 See id. at $33,42,57$.

79 Id. at 21 . 
In sum, "procedure is to law what 'scientific method' is to science.",80 In re Gault rejected the argument that the civil nature of juvenile proceedings, which emphasize rehabilitation over punishment, made them exempt from the ordinary requirements of the Due Process Clause. ${ }^{81}$ The Court explained that "[u]nder our Constitution, the condition of being a boy does not justify a kangaroo court." ${ }^{, 82}$

In re Winship ${ }^{83}$ and Breed $v$. Jones ${ }^{84}$ quickly followed In re Gault. The two cases applied the "guilt beyond a reasonable doubt" standard and Double Jeopardy Clause, respectively, to juvenile court proceedings. Both of the cases focused on the serious consequences of juvenile proceedings. In re Winship observed that "civil labels and good intentions do not themselves obviate the need for criminal due process safeguards in juvenile courts, ${ }^{, 85}$ because delinquency proceedings are "comparable in seriousness" to felony prosecutions. ${ }^{86}$ In Jones, the Court again focused on the nature of juvenile proceedings, commenting that "in terms of potential consequences, there is little to distinguish an adjudicatory hearing such as was held in this case from a traditional criminal prosecution." ${ }^{87}$ Neither of the cases purported to define the totality of the relationship between a minor and the state.

By way of contrast, in McKeiver v. Pennsylvania ${ }^{88}$ the Court held that the Sixth Amendment right to trial by jury does not apply to delinquency proceedings. ${ }^{89}$ A plurality of the Court recognized the failures of the juvenile court system, ${ }^{90}$ but emphasized that imposing a right to trial by jury in a juvenile proceeding would turn it into an adversary hearing without advancing the fact-finding process. ${ }^{91}$

${ }^{80} \mathrm{Id}$.

81 See id. at 27. The Court stated that:

While due process requirements will, in some instances, introduce a degree of order and regularity to Juvenile Court proceedings to determine delinquency, and in contested cases will introduce some elements of the adversary system, nothing will require that the conception of the kindly juvenile judge be replaced by its opposite, nor do we here rule upon the question whether ordinary due process requirements must be observed with respect to hearings to determine the disposition of the delinquent child.

Id.

82 Id. at 28 .

83397 U.S. $358(1970)$.

84421 U.S. 519 (1975).

8s In re Winship, 397 U.S. at 365-66.

${ }^{86}$ Id.

87 Jones, 421 U.S. at 530.

88403 U.S. 528 (1971).

89 See id. at 572.

90 See id. at 545.

91 As the plurality explained:

The Court has refrained, in the cases heretofore decided, from taking the easy way with a flat holding that all rights constitutionally assured for the adult accused are to be imposed upon the state juvenile proceeding.... 
With the sole exception of McKeiver, all of the procedural rights afforded to adults in criminal proceedings are available to juveniles in delinquency proceedings. The fact that the procedural rights of adults and minors are virtually the same, however, does not mean that the Court will readily conclude that the substantive rights of minors and adults are the same. In procedural due process case law involving the rights of minors, the Court has applied only those safeguards that it felt were necessary to enhance the trustworthiness of juvenile proceedings. In each case, the Court was concerned with the procedural fairness of the juvenile proceedings and did not attempt to equate the rights of minors in a general sense to those of adults. Therefore, these cases are not overly helpful when the issue is whether a juvenile has the same right to liberty as an adult.

\section{B. Juvenile Rights and Substantive Liberty}

The Court has recognized that a minor's substantive rights are not coextensive with those of adults. The Court first confronted this issue in Prince v. Massachusetts, ${ }^{92}$ wherein the Court upheld Massachusetts' child labor laws against a constitutional challenge brought under the Equal Protection Clause and the First Amendment. ${ }^{93}$ The child labor law prohibited minors under the age of twelve from selling newspapers or periodicals in any street or public place. ${ }^{94}$ The Court observed that the statute would be unconstitutional if it applied to adults. ${ }^{95}$ Then, in an oft-quoted passage, the Court remarked:

The state's authority over children's activities is broader than over like actions of adults. ... A democratic society rests, for its continuance, upon the healthy, well-rounded growth of young people into full maturity as citizens, with all that im-

The imposition of the jury trial on the juvenile court system would not strengthen greatly, if at all, the factfinding function, and would, contrarily, provide an attrition Id. at $545-47$.

of the juvenile court's assumed ability to function in a unique manner.

${ }_{92} 321$ U.S. 158 (1944).

93 See id. at 169-70. Mrs. Prince, who had legal custody of Betty Simmons (age nine) was a Jehovah's Witness who went door-to-door spreading her religious message. See id. at 162 . Betty went out with Mrs. Prince and carried magazines which, from time to time, she had sold at the rate of five cents per copy. See id.

See id. at 160-61.

9s See id. at 167 ("Concededly a statute or ordinance identical in terms with Section 69, except that it is applicable to adults or all persons generally, would be invalid.") (citations omitted). The Court further stated that "the mere fact a state could not wholly prohibit this form of adult activity ... does not mean it cannot do so for children." Id. at 168. 
plies. It may secure this against impeding restraints and dangers within a broad range of selection. ${ }^{96}$

The precise dimensions of the state's authority over children are still unclear. The Court has struggled over how to define the scope of a minor's rights in cases dealing with the First Amendment rights of minors, and those pertaining to a minor's right to privacy (including the right to obtain an abortion). While these cases do not suggest a precise test for determining the extent of a minor's substantive rights, a couple of general principles are clear. First, the Court has never started from scratch and asked whether a right that exists for adults exists at all for children. In each case, the Court assumes that minors have some constitutional protection. Second, the Court is more likely to show deference to a state law that regulates the conduct of minors.

In several cases dealing with restrictions on the First Amendment rights of minors, the Court has assumed that minors share many of the rights possessed by adults. As the Court declared in Tinker v. Des Moines Independent School District, ${ }^{97}$ minors "are possessed of fundamental rights which the State must respect." In In each of these cases, the Court looked to the body of law it had already developed for adults, and asked whether minors should be treated differently.

Clearly, minors do enjoy a substantial degree of protection under the First Amendment. Thus, in Tinker the Court held that students had a right to wear black armbands in class in protest of the war in Vietnam. ${ }^{99}$ Tinker emphasized that the classroom is quintessentially the "marketplace of ideas," 100 and minors learn best through exposure to a plurality of ideas, rather than one authoritative account of the truth. ${ }^{101}$

96 Id. The Court went on to state that:

It is true children have rights, in common with older people, in the primary use of highways. But even in such use streets afford dangers for them not affecting adults. ... What may be wholly permissible for adults therefore may not be so for children, either with or without their parents' presence. Id. at 169.

97393 U.S. 503 (1969).

98 Id. at 511 .

99 See id. at 514.

too Id. at 512 .

101 See id. at 510-13. The school's decision to suspend students wearing armbands was based solely on the desire to avoid the controversy that would result from open opposition to the Vietnam War. See id. at 510. The Court found that this action was a form of viewpoint based discrimination. See id. at 512-13.

Viewpoint-bassed discrimination upon ideas is particularly repugnant to the Constitution in the arena of the First Amendment. See generally R.A.V. v. City of St. Paul, 505 U.S. 377 (1992). Moreover, as the Court noted in Tinker, "[t]he classroom is peculiarly the "marketplace of ideas.' The Nation's future depends upon leaders trained through wide exposure to that robust exchange of ideas which discovers truth 'out of a multitude of tongues, [rather] than through any kind of authoritative selection." Tinker, 393 U.S. at 512 (quoting Keyishian v. Bd. of Regents, 385 U.S. 589, 603 (1967)). 
The First Amendment rights of minors, however, do not extend to speech that borders obscenity. In Ginsberg v. New York, ${ }^{102}$ the Court held that a state may adjust its statutory definition of obscenity for minors. ${ }^{103}$ Ginsberg emphasized that "even where there is an invasion of protected freedoms 'the power of the state to control the conduct of children reaches beyond the scope of its authority over adults." 104 The Court recognized that the state "has an independent interest in the well-being of its youth."105 The Court then upheld the statute, applying a rational basis test. ${ }^{106}$

Even at the borders of protected speech, however, the state must be careful not to prohibit too much. In Erznoznik v. City of Jacksonville, ${ }^{107}$ the Court struck down a law that prohibited drive-in movie theaters from showing movies that contained any nudity. ${ }^{108}$ One of the arguments advanced by the city in defense of the law was that the statute was a reasonable means of protecting minors from harm, citing Ginsberg. ${ }^{109}$ The Court rejected the argument, stating that "[s]peech that is neither obscene as to youths nor subject to some other legitimate proscription cannot be suppressed solely to protect the young from ideas or images that a legislative body thinks unsuitable for them." ${ }^{110}$ Erznoznik acknowledged, however, that there are some areas where a child " is not possessed of that full capacity for individual

102390 U.S. 629 (1968). The issue in Ginsberg was whether a state may adjust its definition of obscenity for minors. See id. at 631-32. A vendor was charged with selling "girlie" magazines to a 16 year-old boy. See id. The trial judge found that he had violated New York's criminal obscenity statute. See id. The statute defined material containing nudity as harmful to minors where it: "(i) predominantly appeals to the prurient, shameful or morbid interest of minors, and (ii) is patently offensive to prevailing standards in the adult community as a whole with respect to what is suitable material for minors, and (iii) is utterly without redeeming social importance for minors." Id. at 633 .

103 See id. at 642-43.

104 Id. at 638 (citing Prince v. Massachusetts, 321 U.S. 158, 170 (1944)).

105 Id. at 640 . The Court then quoted Chief Judge Fuld of the New York Court of Appeals, who stated that:

[T] he knowledge that parental control or guidance cannot always be provided and society's transcendent interest in protecting the welfare of children justify reasonable regulation of the sale of material to them. It is, therefore, altogether fitting and proper for a state to include in a statute designed to regulate the sale of pornography to children special standards, broader than those embodied in legislation aimed at controlling dissemination of such material to adults.

People v. Kahan, 206 N.E.2d 333, 334 (1965).

106390 U.S. at 641 ("The only question remaining, therefore, is whether the New York Legislature might rationally conclude, as it has, that exposure to the materials proscribed by [the obscenity law] constitutes such an "abuse."').

107 422 U.S. 205 (1975).

las See id. at 216-17.

lios See id. at 212

110 Id. at 213-14. 
choice which is the presupposition of First Amendment guarantees." "111 The Court did not elaborate on what these areas include.

Another principle developed from the Court's case law concerning minors is that legislative classifications concerning minors should receive a greater degree of deference. The Court's right to privacy jurisprudence pertaining to minors demonstrates this principle. While the Court has been unable to agree on a standard of review to apply to classifications that burden a minor's rights, all of the cases show a greater degree of deference than the normal strict scrutiny standard of review that is applied to classifications burdening the rights of adults.

The Court has struggled to formulate a test for alleged infringements of a minor's right to privacy. In Planned Parenthood v. Danforth, ${ }^{112}$ the Court considered the constitutionality of a parental consent provision in Missouri's abortion statute. ${ }^{113}$ Danforth framed the test as "whether there is any significant state interest . . . that is not present in the case of an adult."114

The following year, the Court considered whether a state may prohibit the distribution of contraceptives to minors under the age of sixteen in Carey v. Population Services International. ${ }^{115}$ A plurality of four applied the Danforth test. The plurality observed that this test is "apparently less rigorous than the 'compelling state interest' test applied to restrictions on the privacy rights of adults." 116 The plurality found the lower standard appropriate because: (1) a state has greater latitude to regulate the conduct of minors; and (2) minors have a lesser capacity for making important decisions. ${ }^{117}$

In Bellotti v. Baird, ${ }^{118}$ a plurality elaborated on the reasons for treating cases dealing with the rights of minors differently from those concerning adults:

We have recognized three reasons justifying the conclusion that the constitutional rights of children cannot be equated with those of adults: the peculiar vulnerability of children; their inability to make critical decisions in an informed, ma-

111 Id. at 214 n.11 (citing Ginsberg v. New York, 390 U.S. 629, 649-50 (1968) (Stewart, J., concurring)).

112428 U.S. 52 (1976).

113 See id. at 52 . The applicable section of Missouri's abortion statute required that, in the first twelve weeks of her pregnancy, the minor obtain the written consent of a parent or person in loco parentis if she is under 18 and unmarried unless the abortion was necessary to save the life of the mother. See id. at 58.

114 Id. at 75.

115431 U.S. 678 (1977).

116 Id. at 693 n. 15 .

117 See id.

118443 U.S. 622 (1979). 
ture manner; and the importance of the parental role in child rearing. ${ }^{119}$

Bellotti did not mention or apply the Danforth standard. In fact, this standard has been all but forgotten in the Court's later decisions. In H.L. v. Matheson, ${ }^{120}$ the Court reviewed an abortion statute as it applied to a minor. ${ }^{121}$ At the end of the opinion, the Court stated that the statute "plainly serves important state interests, is narrowly drawn to protect only those interests, and does not violate any of the guarantees of the Constitution." 122 Unfortunately, the Court did not elaborate on the test it was applying, and did not explain how the test was supposed to be applied or what the individual factors meant.

More recently, in Hodgson v. Minnesota, ${ }^{123}$ the Court considered whether a state's two-parent notification provision, without a judicial bypass, violated the Constitution. ${ }^{124}$ The Court again was confused by the question of what standard to apply. Justice Stevens and Justice O'Connor applied a rational basis test, citing Ginsberg. ${ }^{125}$ Justice Marshall, joined by Justices Brennan and Blackmun, expressed the view that minority status does not affect the nature of the right itself, but only the state's interests. ${ }^{126}$ A four-Justice plurality observed that, "[t]he law does not give to children many rights given to adults, and provides, in general, that children can exercise the rights they do have only through and with parental consent." 127 And while the plurality purported to apply some form of rational basis review, in actuality they looked much closer at the justifications for the statute than such a standard of review would imply. ${ }^{128}$

119 Id. at 634 . For an explanation of what the plurality might have meant by these factors, it is helpful to look at what it cited. When discussing a child's "peculiar vulnerability," the plurality discussed the procedure cases set forth above, including In re Winship and In re Gault. See id. When discussing the child's inability to make important, affirmative choices, the Court cited Justice Stewart's opinion in Prince and Ginsberg. See id. at 635-37. For a discussion of Winship and Gault, see supra notes 78-86 and accompanying text. For an explanation of Prince and Ginsberg, see supra notes 92-96, 102-06 and accompanying text.

120450 U.S. 398 (1981).

121 See id. at 398.

122 Id. at 413 (footnote omitted).

123497 U.S. 417 (1990).

124 See id. at 424-25.

125 See id. at $448-49$.

126 See id. at 464 ("Neither the scope of a woman's privacy right nor the magnitude of a law's burden is diminished because a woman is a minor. Rather, a woman's minority status affects only the nature of the State's interests.") (citations omitted).

127 Id. at 482 (citation omitted).

128 See id. at 483-501. Such justifications include the protection of a parent's right to participate in the child's upbringing, the fostering of parent-child relationships, and a general societal interest. See id. at 485-86. 


\section{THE RIGHT TO TRAVEL ON PUBLIC FORA}

"If I choose to take an evening walk to see if Andromeda has come up on schedule, I think I am entitled to look for the distant light of Almach and Mirach without finding myself staring into the blinding beam of a police flashlight."129

There is no consensus among the lower courts regarding either the existence of a fundamental right to travel on public fora or the scope of such a right if it indeed exists. This Part offers a solution to that controversy.

For the most part, the circuit split does not stem from an underlying doctrinal disagreement. Rather, the underlying factual circumstances in the circuit cases show that in each case the court is responding to somewhat different concerns. The constitutional right to travel on public fora is properly understood as an aspect of substantive due process. This right is rooted in our nation's history and traditions, and deserves recognition as a fundamental aspect of the "liberty" protected by the Due Process Clause of the Fourteenth Amendment. Anxiety over the potential consequences of recognizing such a right can be dispelled by adopting a modified formulation of the "undue burden" standard set forth by the joint opinion in Planned Parenthood v. Casey ${ }^{130}$ to determine which level of scrutiny to apply to alleged deprivations of this right.

\section{A. Circuit Split: Doctrinal Disagreement or Sloppy Rights Talk?}

The right to travel on public fora is frequently recognized by courts in general terms as a right to freedom of movement. ${ }^{131}$ The failure of courts to describe this right precisely as a right to travel on public fora has led to a needless and superficial disagreement amongst the circuit courts over whether such a right exists. ${ }^{132}$ The

129 Papachristou v. City of Jacksonville, 405 U.S. 156, 164 n.6 (1972) (quoting Charles A. Reich, Police Questioning of Law Abiding Citizens, 75 YALE L.J. 1161, 1172 (1966)).

${ }_{130} 505$ U.S. 833, 873-78 (1992) (stating that not every burden that makes a right more difficult to exercise is an infringement of that right and that the right is only violated if the state imposes an undue burden on its exercise).

131 See, e.g., Nunez v. City of San Diego, 114 F.3d 935, 944 (9th Cir. 1997) ("Citizens have a fundamental right of free movement, "historically part of the amenities of life as we have known them."') (citations omitted); Cole v. Housing Auth., 435 F.2d 807, 809 (1st Cir. 1970) ("[T]he right to travel is a fundamental personal right that can impinged only if necessary to promote a compelling governmental interest.") (footnote omitted). But see Lutz v. City of York, 899 F.2d 255, 268 (3d Cir. 1990) (recognizing a fundamental "right to travel locally through public spaces and roadways").

${ }_{132}$ Cf. Laurence H. Tribe \& Michael C. Dorf, Levels of Generality in the Definition of Rights, 57 U.CHI. L. REV. 1057, 1067 (1990). As the authors explain:

[A] right to be let alone cannot serve as a constitutional rule of decision. A right to be let alone while doing what? While harming others? Harming others in what way? 
cases involve three distinct factual scenarios: (1) a "right to commute;"133 (2) a right to receive public housing in the context of durational residency requirements; ${ }^{134}$ and (3) a right to travel freely within a given jurisdiction, or a right to travel on public fora. ${ }^{135}$

\section{Right to Commute}

The first scenario involves an employment situation where constitutional rights may be waived by contract. Thus, it was unnecessary for the courts to consider and reject a broadly described right to freedom of movement. ${ }^{136}$ Further, these residency requirements are not justified by a desire to discourage persons from migrating to a community, which is the purpose that Shaprio $v$. Thompson ${ }^{137}$ found unconstitutional. $^{138}$

Three of the four circuit courts that rejected an asserted right to intrastate travel did so in the context of a "right to commute." In Wardwell v. Board of Education, ${ }^{139}$ the Cincinnati Board of Education adopted a resolution that required all teachers to establish residency in the school district within ninety days of starting employment. ${ }^{140}$ In Andre $v$. Board of Trustees, ${ }^{141}$ the Village of Maywood, Illinois adopted a resolution that required all administrative personnel and

As determined by whom? These questions make clear the need for a less abstract formulation of the right at stake....

133 Andre v. Bd. of Trustees, 561 F.2d 48, 52-53 (7th Cir. 1977) (finding that residency requirement for municipal employment did not impermissibly burden plaintiffs' right to interstate or intrastate trave1); Wardwell v. Bd. of Educ., 529 F.2d 625, 627 (6th Cir. 1976) (finding that there was no right to intrastate travel and upholding residency requirement for employment); Wright v. City of Jackson, 506 F.2d 900, 902 (5th Cir. 1975) (determining that there is no support for a fundamental Constitutional "right to commute" which would require a compelling governmental purpose).

See King v. New Rochelle Mun. Hous. Auth., 442 F.2d 646 (2d Cir. 1971) (finding five year residency requirement for admission to public housing violated the Equal Protection Clause); Cole, 435 F.2d at 809 (finding that a two year residency requirement to qualify for subsidized housing violated the Equal Protection Clause).

${ }_{135}$ See Hutchins v. District of Columbia, 188 F.3d 531 (D.C. Cir. 1999) (en banc) (holding that because juveniles had no fundamental right to free movement, intermediate scrutiny was proper, and upheld a curfew law); Nunez, 114 F.3d at 944-46 (applying strict scrutiny to overtum curfew law); Smith v. Avino, 91 F.3d 105, 109 (11th Cir. 1996) (finding that a curfew imposed by a county after a hurricane was not unconstitutionally vague and the court upheld the restriction on travel); Lutz, 899 F.2d at 268-71 (applying intermediate scrutiny to uphold municipal cruising ordinance).

${ }_{136}$ See Andre, 561 F.2d at 53 (rejecting any right of intrastate travel outside of cases involving durational residency requirements).

137 394 U.S. 618 (1969).

133 See id. at 629 ("[T]he purpose of inhibiting migration by needy persons . . . is constitutionally impermissible.").

139529 F.2d 625 (6th Cir. 1976).

140 'See id. at 626.

141561 F.2d 48 (7th Cir. 1977). 
department heads to establish residency in Maywood within two years; all other personnel were given four years to comply. ${ }^{142}$ Similarly, in Wright v. City of Jackson, ${ }^{143}$ the City of Jackson, Mississippi passed a statute that required all civil service employees to maintain their domicile within the city limits during their period of employment. ${ }^{144}$

In each of these cases, the employees brought suit seeking to overturn the statutes that required them to live within the jurisdiction of their employment. In Andre, the court observed that under Shapiro, the fact of residency itself was distinct from the durational residency requirement, and that it was only the latter that is unconstitutional. ${ }^{145}$ The purpose of a residency requirement is to assure that city employees live in the community where they work. Employees who are subject to such a restriction are all subject to it equally. Thus, no group is penalized for moving into the community "late."

More fundamentally, the difference between a residency requirement in the Andre sense and the durational residency requirement of Shapiro is the privity between the Andre employee and the government that passes the law. In Andre, Wright, and Wardwell, the persons affected were governmental employees who were getting paid for what they did. The residency requirement was merely a condition of their employment. Thus, they gave up their rights by bargaining for employment. ${ }^{146}$ By way of contrast, Shapiro involved the eligibility of persons for welfare payments. There was no contract between these welfare recipients and the state.

\section{Durational Residency Requirements}

The decisions in King v. New Rochelle Municipal Housing Authority ${ }^{147}$. and Cole v. Housing Authority ${ }^{148}$ recognized a right to

142 See id. at 49.

143506 F.2d 900 (5th Cir. 1975).

144 See id. at 901.

145 See Andre, 561 F.2d at 52 ('Bona fide residency requirements as continuing conditions of municipal employment rest upon footings significantly different from those of durational residency requirements.").

146 There is precedent for finding constitutional rights waived by signing a contract. See, e.g., D.H. Overmeyer Co. v. Frick Co., 405 U.S. 174, 187 (1972) (holding that procedural due process rights may be waived by contract where such a waiver is made "voluntarily, intelligently, and knowingly ...."). However, such a waiver must be clear and must be made in circumstances that are not unconscionable. See, e.g., Fuentes v. Shevin, 407 U.S. 67, 95-96 (1972) (holding that due process rights cannot be waived by an adhesion contract which stated that upon default a seller may repossess the merchandise).

${ }^{147} 442$ F.2d 646 (2d Cir. 1971). The King court held that a five-year residency requirement for admission to public housing was unconstitutional under the Equal Protection Clause. See id. at 648 . 
intrastate travel in the context of durational residency requirements for public housing. These cases cannot be distinguished in any meaningful sense from Shapiro. The durational residency requirements in King and Cole were justified by the same purposes that Shapiro found unconstitutional. It would be surprising if the constitutionality of such an ordinance turned on the issue of whether it deterred migration by those living in another state, or deterred migration by both those living in another state and people seeking to relocate from a different city within the same state.

Such a result might be squared with Shapiro if the case was based solely upon principles of federalism and a notion of dual citizenship. ${ }^{149}$ Shapiro, however, also rested on grounds of personal liberty. ${ }^{150}$ Thus, to the extent that a durational residency requirement infringes on concepts of personal liberty, such a requirement may be unconstitutional when practiced only against citizens of the same state. ${ }^{151}$ As the Second Circuit stated, within this context "[i]t would be meaningless to describe the right to travel between states as a fundamental precept of personal liberty and not to acknowledge a correlative constitutional right to travel within a state."152

\section{Right to Travel on Public Fora}

Three of the four circuits that have addressed the issue of whether there is a right to travel on public fora found such a right. The Ninth Circuit recognized this right in broad terms in a case involving a juvenile curfew law. ${ }^{153}$ The Eleventh Circuit recognized this right in the context of an emergency curfew applicable to both chil-

148435 F.2d 807 (1st Cir. 1970). Cole held that a two-year residency requirement for admission to public housing was unconstitutional under the equal protection clause. See id. at $813-$ 14.

149 See, e.g., Slaughter House Cases, 83 U.S. 36, 77 (1872). Elaborating upon the meaning of the Fourteenth Amendment Privileges or Immunities Clause, the Court stated:

Its sole purpose was to declare to the several States, that whatever those rights, as you grant or establish them to your own citizens, or as you limit or qualify, or impose restrictions on their exercise, the same, neither more nor less, shall be the Id. measure of the rights of citizens of other States within your jurisdiction.

iso As the Shapiro Court explained:

This Court long ago recognized that the nature of our Federal Union and our constitutional concepts of personal liberty unite to require that all citizens be free to travel throughout the length and breadth of our land uninhibited by statutes, rules, or regulations which unreasonably burden or restrict this movement. 394 U.S. 618, 629 (1969) (emphasis added).

151 A full exploration of this issue is beyond the scope of this Note.

152 King, 442 F.2d at 648.

153 See Nunez v. City of San Diego, 114 F.3d 935, 946 (9th Cir. 1997) (holding that the right of travel by children is fundamental and thus applying strict scrutiny analysis to a municipal juvenile ordinance). 
dren and adults. ${ }^{154}$ Finally, the Third Circuit recognized the "right to travel locally through public spaces and roadways" in the context of an anti-cruising ordinance. ${ }^{155}$ Only the D.C. Circuit refused to recognize such a right. ${ }^{156}$

Judge Silberman's plurality opinion in Hutchins v. District of Columbia ${ }^{157}$ subsumes a child's minority status into the definition of the right itself. ${ }^{158}$ Judge Silberman justifies this choice on judicial restraint grounds. The more general the definition of the right is, the argument runs, the easier it is to extend the bounds of substantive due process. ${ }^{159}$ Thus, to ensure against unlicensed judicial lawmaking, the - right must be described at "the most specific level at which a relevant tradition protecting, or denying protection to, the asserted right can be identified. $" 160$

Ironically, in the context of a right to free movement, the opposite is true. As this Part demonstrates, the main reason why this right has not won universal approval is because it remains in abstract form and thus encompasses a wide range of interests (some of which should not enjoy fundamental right status) ${ }^{161}$ Furthermore, incorporating a child's minority status into the definition of an asserted fundamental right is contrary to Supreme Court precedent. ${ }^{162}$

154 See Smith v. Avino, 91 F.3d 105, 109 (11th Cir. 1996) (holding that the right to travel may be temporarily limited or suspended in emergency situations).

155 Lutz v. City of York, 899 F.2d 255, 268-69 (3d Cir. 1990). The court held that one's right to move about town implicates the Due Process Clause. See id. at 268. However, the Court applied intermediate scrutiny, and not strict scrutiny, to the anti-cruising ordinance. See $\mathrm{id}$. at 268-70.

156 See Hutchins v. District of Columbia, 188 F.3d 531, 538-39 (D.C. Cir. 1999) (en banc) (concluding, in a plurality opinion, that juveniles do not have a fundamental right, without adult supervision, to be on the streets).

157188 F.3d 531 (D.C. Cir. 1999) (en banc).

158 See id. at 538 ("[W]e must ask not whether Americans enjoy a general right of free movement, but rather whatever are the scope and dimensions of such a right (if it exists), do minors have such a substantive right?").

${ }_{159}$ See id. (" $[\mathrm{T}]$ he more general is the right's description, i.e., the free movement of people, the easier is the extension of substantive due process.").

${ }_{160}$ Id. (quoting Michael H. v. Gerald D., 491 U.S. 110, 127 n.6 (1988)). Justice Scalia, writing for the majority, took an approach to identifying and defining fundamental rights that has been subjected to harsh criticism. See, e.g., Tribe \& Dorf, supra note 132, at 1086 (arguing that Scalia's approach is not value-neutral, and that there is no one way to measure the appropriate level of generality for an asserted right).

161 One of the main problems with the approach taken by Justice Scalia in Michael H, see supra note 160 and accompanying text, is that it provides no criterion for achieving the proper degree of specificity. A definition may be narrow along one axis, yet broad along another. Thus, while my definition of the right to travel on public fora is more general in the sense that it includes minors, it is also more specific. Unlike a generalized right to free movement (which could be read to authorize travel anywhere), the right as I define it does not prima facie include a right to trespass on private property or gain unauthorized admittance to secure government buildings.

${ }_{162}$ See supra Part II.B (tracing the Supreme Court's development of substantive rights for juveniles). 
The Third Circuit found a fundamental "right to travel locally through public spaces and roadways" in the Due Process Clause. ${ }^{163}$ The court conceded that "this bottom-line judgment is unquestionably ad hoc, to some extent." ${ }^{.164}$ The Third Circuit seemed terrified by the consequences of not finding such a right, ${ }^{165}$ and felt that recognition of this right "is a judgment we are required to make."166

The right to move freely involved in scenario three above is of a different magnitude, if not a different kind, than the right implicated in scenario two. It is one thing to discourage a family from changing their residency, and quite another to discourage them from leaving their house at all. Therefore, it simply will not do to put both of these rights together into the general category of "freedom of movement." 167 While the one right could be described as the "right to migrate with intent to reside," the other must be described as the right to travel on public fora. ${ }^{168}$

\section{B. The Right to Travel on Public Fora}

The right to travel on public fora is a liberty interest that is protected by the Due Process Clause of the Fourteenth Amendment. ${ }^{169}$

163 Lutz v. City of York, 899 F.2d 255, 268 (3d Cir. 1990).

164 Id.

I65 See id. ('Under York's view, a state or local government could constitutionally prohibit all freedom of movement that does not involve interstate migration, interstate commerce, business between a citizen and the federal government, and (presumably) travel incident to otherwise protected activity.").

166 Id.

167 These two rights should also be kept separate because they draw upon separate histories. For a history of the right to migration, see CHAFEE, supra note 57, at 176-93 (describing the history of migratory freedom between the English colonies, the relevant language in the Articles of Confederation, and the rights' history since the adoption of our Constitution). The right to travel on public fora has its own common law history. See infra Part II.B.

${ }_{168}$ This latter right is developed more clearly below. See infra Part III.B.

169 Perhaps no portion of the Court's jurisprudence has created more controversy than its forays into substantive due process. See, e.g., Paul Brest, The Fundamental Rights Controversy: The Essential Contradictions of Normative Constitutional Scholarship, 90 YALE L.J. 1063, 1068-89 (1981) (canvassing various arguments for and against the legitimacy of fundamental rights). Many scholars have defended the Court's expansive decisions by arguing that certain moral principles underlie the abstract phrase "due process of law," and that these principles must be recognized and adhered to if our government is to be considered democratic. See, e.g., Ronald Dworkin, The Arduous Virtue of Fidelity: Originalism, Scalia, Tribe, and Nerve, 65 FORDHAM L. REV. 1249, 1264 (1997) ("Majority rule is democratic only when certain prior conditions-the democratic conditions of equal membership-are met and sustained."); James E. Fleming, Securing Deliberative Autonomy, 48 STAN. L. REv. 1, 62 (1995) ("[D]ue process should secure a forward-looking antitotalitarian principle, criticizing historical practices that deny the promise of liberty ....") (citation omitted). Critics of the Court have argued that these decisions are anti-democratic and do not respect the Constitution's original meaning. See ANTONIN SCALIA, Common-Law Courts in a Civil-Law System: The Role of the United States Federal Courts in Interpreting the Constitution and Laws, in A MATTER OF INTERPRETATION: FEDERAL COURTS AND THE LAW 3, 41 (1997) ("Neither the text of such a document nor the intent of its framers (whichever you choose) can possibly lead to the conclusion that its only 
Indeed, this liberty interest has always been protected from encroachment by the Due Process Clause. It is a mirror-like reflection of the historical meaning of due process; namely, "liberty from bodily restraint." As such, it is a fundamental right that may not be abridged without demonstrating a compelling governmental interest.

\section{The Magna Charta and English Common Law}

"The phrase, "life, liberty or property without due process of law' came to us from the English common law."171 "Due process of law" is the rough equivalent of the phrase "by the law of the land" that appears in the thirty-ninth article of Magna Charta. ${ }^{172}$ The latter phrase includes freedom from bodily restraint. ${ }^{173}$ As one author explains, "[a]ltogether, it may be said that the history of the growth and development of the right of personal liberty is the main element in the history of early English constitutional law."174

Unsurprisingly, when Blackstone spoke of the rights of persons in his commentaries on the English law, he included "personal liberty." "[P]ersonal liberty consists in the power of loco-motion, of changing situation, or removing one's person to whatsoever place one's own inclination may direct; without imprisonment or restraint, unless by due course of law."175 If the right to exercise one's "power

effect is to take the power of changing rights away from the legislature and give it to the courts."). The Court itself has responded to this conflict by stating that "[a]s a general matter, the Court has always been reluctant to expand the concept of substantive due process because guideposts for responsible decisionmaking in this unchartered area are scarce and open-ended." Collins v. Harker Heights, 503 U.S. 115, 125 (1992) (citation omitted).

In an effort to reconcile these competing visions of the judicial role, the Court has attempted to limit the liberties recognized as fundamental under the due process clause to those "which are, objectively, 'deeply rooted in this Nation's history and tradition."' Washington v. Glucksberg, 521 U.S. 702, 720-21 (1997) (citation omitted). This inquiry is backward-looking and protects against short-term departures from historical practices. See County of Sacramento v. Lewis, 523 U.S. 833, 858 (1997) (Kennedy, J., concurring).

170 On several occasions, the Supreme Court confirmed that freedom from bodily restraint is at the core of the liberty protected by the due process clause. See Foucha v. Louisiana, 504 U.S. 71, 80 (1992) ("Freedom from bodily restraint has always been at the core of the liberty protected by the Due Process Clause .... ") (citing Youngberg v. Romeo, 457 U.S. 307, 316 (1982)); Ingraham v. Wright, 430 U.S. 651, 673-674 (1977) ("While the contours of . . . [the liberty interests protected by the Due Process Clause] have not been defined precisely, they have always been thought to encompass freedom from bodily restraint and punishment.").

171 Charles Warren, The New "Liberty" Under the 14th Amendment, 39 HARV. L. REv. 431,440 (1926) (stating that under the common law, "liberty" meant simply liberty of the person or, in other words, the right to have one's person free from bodily restraint).

172 See Charles E. Shattuck, The True Meaning of the Term "Liberty" in those Clauses in the Federal and State Constitutions Which Protect "Life, Liberty, and Property," 4 HARV. L. REV. 365, 372-73 (1891).

${ }^{173}$ See id. at 375 (stating that in the American context, the term "liberty" entails freedom of the person from restraint).

Id. at 376.

1751 WILliam BlaCKSTONE COMMENTARIES *134. 
of loco-motion" did not exist, "there would soon be an end of all other rights and immunities."176

This right was so important that it could not be revoked except in an emergency. ${ }^{177}$ " "Next to a man's life the nearest thing that concerns him is freedom of his person; for indeed, what is imprisonment but a kind of civil death?" "178 In this sense, the right to personal liberty is an autonomy right that arises out of respect for the dignity of the person.

A government violated the right to personal liberty whenever a person was imprisoned without cause. Imprisonment was defined broadly, so that "[t]he confinement of the person, in any wise, is an imprisonment." ${ }^{\prime \prime 79}$ Thus, confining a person to the boundaries of his own home was an imprisonment, as was forcibly detaining him in the street. ${ }^{180}$

\section{Supreme Court Case Law}

This central meaning of the Due Process Clause (protecting a citizen's freedom from bodily restraint) ${ }^{181}$ is so well understood that it is an afterthought in the Court's opinions. Beginning with Meyer $v$. Nebrask $a^{182}$ and continuing through Foucha $v$. Louisiana, ${ }^{183}$ the Court has consistently assumed that the Due Process Clause "encompass[es] freedom from bodily restraint and punishment."184 Indeed, the Court has been "careful not to 'minimize the importance and fundamental nature' of the individual's right to liberty." 185

A necessary corollary of this freedom from bodily restraint is the right of a citizen to "remove from one place to another according to inclination." 186 The ability to move about within a community is "simply another way of saying that you are not imprisoned."187 Thus, "freedom of locomotion may well be treated as a part of freedom of

176 Id. at $* 134-35$.

177 Id. at $* 135$.

178 Shattuck, supra note 172, at 378 (quoting CARE's ENGLISH LIBERTIES 185 (1721)).

179 BLACKSTONE, supra note 175 , at 135.

160 See id.

181 See Jacobus tenBroek, The Constitution AND The Right of Free Movement 6 (1955) ("In fact, though the word liberty in the due process clause has come over the years to be filled with much additional content, this meaning . . . is the primary and historical meaning.").

162262 U.S. 390 (1923). The Meyer Court stated that "[w]ithout doubt, it denotes not merely freedom from bodily restraint." Id. at 399 (emphasis added).

183 504 U.S. 71 (1992). The Foucha Court declared that "[f]reedom from bodily restraint has always been at the core of the liberty protected by the Due Process Clause from arbitrary governmental action." Id. at 80 (citation omitted).

184 Ingraham v. Wright, 430 U.S. 651, 673-74 (1977).

18s Foucha, 504 U.S. at 80 (quoting U.S. v. Salerno, 481 U.S. 739, 750 (1987)).

Is6 Williams v. Fears, 179 U.S. 270, 274 (1900).

187 TENBROEK, supra note 181 , at 6. 
restraint of the person." 188 This freedom has been recognized in the Court's dicta.

The Court's decisions holding loitering and vagrancy laws unconstitutional on vagueness grounds frequently allude to the existence of such a right. In Papachristou v. City of Jacksonville, ${ }^{189}$ the Court stated that walking and strolling are "historically part of the amenities of life as we have known them." 190 Again, in Kolender v. Lawson ${ }^{191}$ the Court observed that a loitering ordinance "implicates consideration of the constitutional right to freedom of movement." 192 Finally, in City of Chicago v. Morales ${ }^{193}$ a plurality of the court declared that "[w]e have expressly identified this 'right to remove from one place to another according to inclination' as 'an attribute of personal liberty' protected by the Constitution."194 The plurality did not consider whether this right would support a substantive due process challenge. ${ }^{195}$

The right to travel on public fora is also logically implied by the right to interstate travel itself, whose existence is no longer questioned. ${ }^{196}$ At least prior to the 20th century and the invention of the airplane (and perhaps the 19th century and the invention of the locomotive engine), it is difficult to imagine how one could exercise their right to interstate travel without the use of public sidewalks and roadways. Even now, most people must use public streets and sidewalks to access airports. Thus, recognition of a right to interstate travel compels the recognition of a right to travel on public fora, lest the former right be reduced to a dead letter.

\section{The Right to Travel and an "Undue Burden"}

Restrictions on the right to travel on public fora that eliminate the utility of the right should be unconstitutional unless justified by a "compelling governmental interest." It does not follow, however, that all restrictions that incidentally burden this right need to satisfy this high threshold. As the Supreme Court has explained:

188 Warren, supra note 171 , at 450 . Warren stated that William v. Fears did not add, substantively, anything to the Due Process Clause. See id.

189405 U.S. 156 (1972).

190 Id. at 164.

191461 U.S. 352 (1983).

192 Id. at 358.

193119 S. Ct. 1849 (1999).

194 Id. at 1857 (citation omitted).

195 See id. at $1863 \mathrm{n} .35$ ("[]]t [is] unnecessary to reach the question whether the ... ordinance is invalid as a deprivation of substantive due process.").

196 See supra Part I (tracing the development of the right to interstate travel). 
The authority of a municipality to impose regulations in order to assure the safety and convenience of the people in the use of public highways has never been regarded as inconsistent with civil liberties but rather as one of the means of safeguarding the good order upon which they ultimately depend. ${ }^{197}$

Thus, the question is how much of an impact must a regulation have before it is considered an infringement of a fundamental right.

The Third Circuit dealt with this issue in Lutz v. City of York. ${ }^{198}$ The Lutz court proposed an "intermediate" standard of review for all alleged violations of the right to intrastate travel, relying on Supreme Court precedents in the arena of time, place, and manner restrictions on speech. ${ }^{199}$ The court reasoned that "[i]f the freedom of speech itself can be so qualified, then surely the unenumerated right of localized travel can be as well." 200 The Lutz court recognized that content-

197 Cox v. New Hampshire, 312 U.S. 569, 574 (1941).

198899 F.2d 255 (3d Cir. 1990). The Lutz court framed the issue as follows: "We believe that reviewing all infringements on the right to travel under strict scrutiny is just as inappropriate as applying no heightened scrutiny to any infringement on the right to travel not implicating the structural or federalism-based concerns of the more well-established precedents." Id. at 269.

199 See id. In applying intermediate scrutiny, the court held that the cruising ordinance "will be upheld if it is narrowly tailored to meet significant city objectives." Id. at 270.

${ }^{200}$ Id at 269. The Court gave two justifications for this analogy. First, the Court stated that not all "burden[s] on First Amendment rights [are] sufficiently serious to trigger heightened scrutiny." Id. at 270 n.41. This is true, but largely beside the point. Similar distinctions have been made in case law dealing with privacy rights as well. In Zablocki v. Redhail, 434 U.S. 374 (1978), the Court considered a Wisconsin statute which prevented parents who paid child support and who did not have custody of the child from marrying without court approval. See id. at 375. The Court observed that only regulations which "interfere directly and substantially with the right to marry" were subject to a strict scrutiny standard of review. Id. at 386-87. The Zablocki court then distinguished Califano v. Jobst, 434 U.S. 47 (1977), which involved a provision of the Social Security Act that cut off disability benefits to a person who married someone who was not separately entitled to benefits. See id. at 48 . The Court distinguished Califano on the ground that the burden in Zablocki was more direct and substantial an interference with the right to marry. See Zablocki, 434 U.S. at 387 n.12 ("The statutory classification at issue here, [in contrast to Califano], clearly does interfere directly and substantially with the right to marry."). As one scholar has observed, "[t]he only reason for the more rigorous scrutiny applied in Zablocki is the fact that the burden on the right to marry in that case was more severe than it was in Califano." Alan Brownstein, How Rights are Infringed: The Role of Undue Burden Analysis in Constitutional Doctrine, 45 HASTINGS L.J. 867, 896 (1994). Thus, the fact that First Amendment jurisprudence has a mechanism for dealing with insubstantial burdens does not by itself justify this analogy.

Second, the Lutz court found the First Amendment analogy helpful because of the Supreme Court's forum analysis. See Lutz, 899 F.2d at 270 n.41. The court reasoned that, just as heightened scrutiny is appropriate in speech cases only where the forum is a public one, it is also appropriate in "localized" travel cases only where the forum is a public one. See id. This is true, but the same problem may be addressed by carefully describing the right. My description of the right to travel on public fora encompasses the fora that are considered by the Court to be public. Therefore, the analogy is unnecessary in this respect as well. 
based restrictions on speech merit strict scrutiny, ${ }^{201}$ but felt that the content-neutrality requirement in free speech cases had "no obvious analog in the travel context.,"202

Content-based restrictions on speech are treated differently from content-neutral restrictions because "content discrimination 'raises the specter that the Government may effectively drive certain ideas or viewpoints from the marketplace." ${ }^{203}$ A regulation is content-neutral when it is justified not by hostility to the content of the speech, but by the "secondary effects" of the speech on the community. ${ }^{204}$ As Professor Dorf explains, "[c]ontent-based regulations aim at the communicative impact of communicative activity, whereas content-neutral regulations merely have an adverse effect on communicative opportunity." ${ }^{205}$ Thus, content-neutral regulations impose, at most, incidental burdens on core First Amendment values.

Missing from the Lutz test is a mechanism for distinguishing burdens on the right to travel on public fora that are incidental (such as traffic lights) from those that are direct (such as a curfew law). The Lutz test treats both categories of burdens identically. As a consequence, the Lutz test is both overprotective and underprotective.

The test is overprotective because it would require that traffic signals, stop signs, and right-of-way designations survive an intermediate standard of review. These regulations are meant to facilitate the right to travel, not burden it. They are necessary to keep the roadways safe. Without them, the right to travel as we know it would not exist because streets would be covered with traffic accidents. Cities should not be forced to prepare detailed analyses of the purposes of each stop sign to justify them. Unless the placement of traffic signals and the like causes a substantial disruption of a person's ability to travel, such burdens should not be subject to heightened scrutiny at all.

Lutz is also underprotective because it evaluates direct burdens on the right to travel on public fora under an intermediate standard of review. Traditionally, laws that directly burden a fundamental right must survive strict scrutiny by demonstrating that they are narrowly

201 See id. at $270 \mathrm{n} .40$ ("Only content-neutral restrictions are subjected to intermediate scrutiny in the public fora cases. Content-specific restrictions, by contrast, must survive strict scrutiny.") (citation omitted).

202 Id.

203 R.A.V. v. City of St. Paul, 505 U.S. 377, 387 (1992) (quoting Simon \& Schuster, Inc., v. Members of the New York State Crime Victims Board, 502 U.S. 105, 116 (1991)).

204 See City of Renton v. Playtime Theatres, 475 U.S. 41, $47-48$ (1986) (holding that a zoning ordinance that prohibited theaters from showing non-obscene pornographic films was content neutral because it was justified by the secondary effects of adult theaters on the community, including prostitution).

205 Michael C. Dorf, Incidental Burdens on Fundamental Rights, 109 HARV. L. REV. 1175, 1201 (1996). 
drawn to serve a compelling governmental interest. ${ }^{206}$ There is no compelling reason for treating the right to travel on public fora differently from all other fundamental rights.

The best method for distinguishing between those burdens that justify heightened scrutiny and those that do not is the "undue burden" standard adopted by a plurality in Planned Parenthood $v$. Casey. ${ }^{207}$ This is a threshold inquiry. ${ }^{208}$ Once an undue burden is found, the regulation is subject to strict scrutiny. If there is no "undue burden," then the regulation merely has to pass rational basis review. This mechanism eliminates the problems of overinclusion and underinclusion that are caused by the Lutz test.

A statute or regulation constitutes an undue burden where it "has the purpose or effect of placing a substantial obstacle in the path" of the exercise of the right. ${ }^{209}$ Thus, the inquiry is whether a state or municipality has placed a substantial obstacle in the path of a person's right to travel on public fora. The right to travel on public fora is one of those rights that, as Professor Dorf explains, "presuppose[s] the existence of conditions such that a regulation that appears to burden a right could actually be consistent with the assumptions that define the right." ${ }^{210}$ As the Lutz court observed, certain types of regulations are necessary for the right to travel upon public parks, sidewalks, and roadways to have meaning. ${ }^{211}$ This right assumes that regulations providing for a right-of-way and other necessities for organized and orderly travel exist; otherwise, accidents occur and every hour ends

206 See id. at 1177-78 (distinguishing between strict level of scrutiny applied to laws that directly burden a fundamental right and more deferential scrutiny applied to laws that only incidentally burden a fundamental right).

207505 U.S. 833 (1992). In Casey, the plurality evaluated the constitutionality of six separate provisions of the Pennsylvania abortion statute. See id. at 879-901. The plurality found the statute's definition of medical emergency, informed consent requirement, 24-hour waiting period requirement, parental consent requirement, and most of the record keeping and reporting requirements to be constitutional. See id. at $880-87,899-901$. The plurality found the spousal notification provision, and the portion of the reporting requirement which mandated that a woman failing to notify her spouse give a reason for that failure, to be unconstitutional. See id. at $887-98,901$.

${ }^{203}$ See Brownstein, supra note 200 , at $879-80$. This author argues that the Casey plurality collapses the threshold standard with the strict scrutiny analysis in the context of abortion. This argument stems from the Court's understanding of the "right/infringement/justification interrelation," which assumes that there is no "sufficiently compelling interest" before viability that would warrant that level of interference with a woman's right to choose an abortion. See id.

${ }_{209}$ Id. at 878 (quoting Planned Parenthood v. Casey, 505 U.S. 833, 877 (1992) (Scalia, J., concurring in part and dissenting in part)).

210 Dorf, supra note 205, at 1226.

211 As the Lutz court explained:

[T] he right to travel cannot conceivably imply the right to travel whenever, wherever and however one pleases-even on roads specifically designed for public travel. Unlimited access to public fora or roadways would result not in maximizing individuals' opportunity to engage in protected activity, but chaos.

Lutz v. City of York, 899 F.2d 255, 269 (3d Cir. 1990). 
up looking like rush hour. In other words, a right to travel assumes a right to orderly travel and not merely disjointed movement in an abstract sense.

Thus, a strict scrutiny standard of review should only apply to incidental burdens on the right to travel that do not facilitate its exercise and impose, in the words of Casey, a "substantial obstacle" in the path of the exercise of this right. This inquiry is objective and from the point of view of the individual traveller. ${ }^{212}$ If such an obstacle does not exist, then rational basis review is warranted.

Under such a standard, Lutz is an easy case. An "anti-cruising" ordinance is clearly facilitative of the right to travel upon public streets. It has as its principal objective the removal of traffic congestion, which is necessary for orderly and efficient travel. The ordinance does not place a substantial obstacle in the way of anyone exercising their fundamental right to travel upon public streets. It merely requires persons to travel with some particular destination in mind, or, if not, that one at least wanders aimlessly rather than in circles.

Adopting such a standard with respect to all adults will secure a citizen's right to travel on public fora while minimizing unwarranted judicial interference with respect to the legitimate regulatory concerns of states and local governments. Assuming that the regulation does impose an undue burden, this Note now turns to the question of whether the same standard of review (e.g., strict scrutiny) should apply to the rights of juveniles.

${ }^{212}$ The Seventh Circuit, in Hope Clinic v. Ryan, 195 F.3d 857 (7th Cir. 1999), took a different position. Writing for the majority, Judge Easterbrook stated that:

[O]ur best estimate is that 'undue' rather than 'burden' is the key word, and that 'undue' means not only 'substantial' (a small cost or inconvenience is not 'undue') but also that the burden must be undue in relation to the woman's interests, rather than undue in relation to the court's assessment of society's interests.

Id. at 874. Judge Posner, however, adopted the view that courts should conduct the inquiry from an objective standpoint. He accordingly stated that "if a statute burdens constitutional rights and all that can be said on its behalf is that it is the vehicle that legislators have chosen for expressing their hostility to those rights, the burden is undue." Id. at 881 . 


\title{
IV. FINDING A STANDARD OF REVIEW FOR JUVENILE RIGHTS
}

\author{
"But the word 'right' is one of the most deceptive of pitfalls; \\ it is so easy to slip from a qualified meaning in the premise \\ to an unqualified one in the conclusion. Most rights are \\ qualified.",213
}

The Supreme Court's confusing pronouncements on the issue of juvenile rights ${ }^{214}$ forced the lower courts to deduce a standard of review to apply when considering the constitutional rights of minors under curfew laws. It should come as little surprise that the results have not been uniform. Much of the confusion revolves around the Court's opinion in Bellotti v. Baird. ${ }^{215}$ Although the Bellotti plurality viewed its criteria as a rationale for treating the rights of minors differently in a general sense, ${ }^{216}$ lower courts have latched onto this opinion as providing a test for whether or not the rights of minors should be treated differently. ${ }^{217}$

Many of these courts have applied the Bellotti factors to the right asserted. ${ }^{218}$ Others have applied these factors to the nature of the government's interests. ${ }^{219}$ None of the courts that have applied these factors to either prong of the analysis offered an elaborate or fully adequate justification for why they have applied Bellotti.

\section{A. Fundamental Rights and the Strict Scrutiny Alternative}

As noted above, no clear standard of review has emerged for analyzing the constitutional rights of juveniles. Many courts and com-

\footnotetext{
${ }^{213}$ American Bank \& Trust Co. v. Fed. Reserve Bank of Atlanta, 256 U.S. 350, 358 (1921).

${ }^{214}$ See supra Part II (tracing Supreme Court development of juvenile rights).

215443 U.S. 622 (1979).

${ }^{216}$ See supra note 119 and accompanying text.

217 See, e.g., Nunez v. City of San Diego, 114 F.3d 935 (9th Cir. 1997); Schleifer v. City of Charlottesville, 963 F. Supp. 534 (W.D. Va. 1997); Gaffney v. Allentown, Civ. No. 97-4455, 1997 U.S. Dist. LEXIS 14565 (E.D. Pa. Sept. 17, 1997); McCollester v. City of Keene, 586 F. Supp. 1381 (D.N.H. 1984); In re Appeal in Maricopa County, 887 P.2d 599 (Ariz. Ct. App. 1994); In re J.M., 768 P.2d 219 (Colo. 1989); City of Maquoketa v. Russell, 484 N.W.2d 179 (lowa 1992); City of Panora v. Simmons, 445 N.W.2d 363 (Iowa 1989); Brown v. Ashton, 611 A.2d 599 (Md. Ct. Spec. App. 1992); Allen v. City of Bordentown, 524 A.2d 478 (N.J. Super. Ct. Law Div. 1987); Washington v. J.D., 937 P.2d 630 (Wash. Ct. App. 1997); see also Note, Assessing the Scope of Minors' Fundamental Rights: Juvenile Curfews and the Constitution, 97 HARV. L. REv. 1163, 1175-80 (1984) [hereinafter Juvenile Curfews and the Constitution] (arguing that courts should apply the Belloti criteria in assessing curfew ordinances to determine whether such ordinances serve any interests that are compelling for children).

218 See, e.g., Schleifer, 963 F. Supp. at 541-42; Gaffney, 1997 U.S. Dist. LEXIS 14565, at *13-*14.

${ }^{219}$ See, e.g., Nunez, 114 F.3d at 945-46.
} 
mentators continue to advocate a strict scrutiny standard. ${ }^{220}$ Courts that advocate the use of a fundamental rights/strict scrutiny analysis for regulations burdening children typically do so with the caveat that children's rights may be burdened to a greater extent than those of adults. ${ }^{221}$ Ordinarily, when a fundamental right or suspect class is burdened by a legislative classification, that classification is subjected to strict scrutiny and struck down unless the state has a compelling governmental interest and the legislation is narrowly tailored to further that interest. ${ }^{222}$ However, proponents of fundamental rights for children do not argue that the strict scrutiny analysis should be applied in this form. Instead, they argue that courts should apply a "modified" form of strict scrutiny that recognizes interests that are "compelling for children." $" 223$

In order to determine which interests are compelling for children, courts and commentators that follow this mode of analysis have usually looked to Bellotti v. Baird..$^{224}$ The Bellotti plurality identified three factors which justify differential treatment for the constitutional rights of children: (1) a child's "peculiar vulnerability"; (2) a child's "inability to make critical decisions in an informed, mature manner"; and (3) the role of the parent in the development of the child. ${ }^{225}$ Courts that afford minors fundamental rights then look to the Bellotti

220 See generally Nunez v. City of San Diego, 114 F.3d 935 (9th Cir. 1997); In re Appeal in Maricopa County, 887 P.2d 599 (Ariz. Ct. App. 1994); City of Maquoketa v. Russell, 484 N.W.2d 179 (Towa 1992); Brown v. Ashton, 611 A.2d 599 (Md. Ct. Spec. App. 1992); see also Susan M. Horowitz, A Search for Constitutional Standards: Judicial Review of Juvenile Curfew Ordinances, 24 COLUM. J. L. \& SOC. PROBS. 381, 415 (1991) (arguing in favor of a form of strict scrutiny analysis which would recognize those state interests that are "compelling for children"); Juvenile Curfews and the Constitution, supra note 217, at 1171 (arguing that children's rights should be viewed as fundamental, and that courts should apply strict scrutiny to analyze constitutional challenges on the basis of those rights).

${ }_{221}$ See, e.g., Nunez, 114 F.3d at 945 ('[M]inors' rights are not coextensive with the rights of adults because the state has a greater range of interests that justify the infringement of minors' rights.").

${ }_{222}$ See, e.g., Adarand Constructors, Inc. v. Pena, 515 U.S. 200, 237 (1995) ("When racebased action is necessary to further a compelling interest, such action is within constitutional constraints if it satisfies the 'narrow tailoring' test ....").

223 Horowitz, supra note 220 , at 415 . As another commentator explains:

The principle of strict scrutiny for infringements of fundamental rights presupposes a universe of citizens equal under the Constitution; what qualifies as a compelling state interest does not ordinarily vary depending on which citizens are affected .... Thus, to recognize special interests surrounding one unique class of citizens-children-is to recognize the need for a unique form of strict scrutiny. Such a form of review would acknowledge compelling state interests that pertain only to children.

Juvenile Curfews and the Constitution, supra note 217, at $1171-72$ (citation omitted).

224443 U.S. 622 (1979).

225 Id. at 634. 
factors to ascertain if there is a compelling interest that justifies the curfew ordinances. ${ }^{226}$

This analysis improperly conflates concerns relevant to defining fundamental rights with those appropriate to ascertaining compelling governmental purposes. Fundamental rights are negative rights-they restrict the sphere of government action. ${ }^{227}$ Compelling governmental interests, on the other hand, justify why the government has acted. ${ }^{228}$ Whereas fundamental rights concern liberties retained by the people, compelling interests concern a government's need to act in a certain situation. $^{229}$

A minor's vulnerability, or inability to make critical decisions, pertains to whether (or not) a child has a fundamental right, not whether the government has a compelling interest. Many fundamental rights stem from a personal interest in autonomy. As Professor Fallon explains:

As beings who are capable of self-direction, we have an interest in being able to make decisions for ourselves and to act on those decisions that is sometimes independent of the interest in having the decision made that will be best for us in the sense of producing the greatest after-the-fact well-being. ${ }^{230}$

This interest, however, presupposes the capacity to act as a fully autonomous person. ${ }^{231}$ Where this capacity is not fully present, this

226 See, e.g., Nunez, 114 F.3d at 945 ("The Bellotti framework enables courts to determine whether the state has a compelling interest justifying greater restrictions on minors than on adults.") (citations omitted); In re Appeal of Maricopa County, 887 P.2d 599, 606-07 (phrasing the issue as "whether a significant state interest not present in the case of an adult justifies infringing upon minors' fundamental rights"); City of Maquoketa v. Russell, 484 N.W.2d 179, 185-86 (Iowa 1992) (citing Bellotti to state that "an ordinance which restricts minors' rights to an extent greater than it restricts adults" rights may be sustained if the State or municipality demonstrates that it protects minors' peculiar vulnerability, accounts for their lesser ability to make sound judgments, and reflects society's deference to the guiding role of parents").

227 See Erwin Chemerinsky, Constitutional Scholarship in the 1990s, 45 HASTINGs L.J. 1105,1115 (1994) (distinguishing between rights, which are negative because they restrict what government can do, and interests, which involve justifications for why government has affirmatively acted).

228 See id.

229 See id.

230 Richard H. Fallon, Jr., Individual Rights and the Powers of Government, 27 GA. L. REV. 343, 354 (1993) (footnote omitted).

231 See David A.J. Richards, Sexual Autonomy and the Constitutional Right to Privacy: A Case Study in Human Rights and the Unwritten Constitution, 30 HASTINGS L.J. 957, 964 (1979). As this commentator explains, two critical assumptions underly all concepts of human rights: "first, that persons have the capacity to be autonomous in living their life [sic]; second, that persons are entitled, as persons, to equal concern and respect in exercising their capacities for living autonomously." Id. (emphasis in original). 
interest (and a fortiori the constitutional rights that it supports) is diminished.

Saying that a minor is "vulnerable," or that he or she is unable to make critical decisions, is simply another way of stating that minors do not yet possess the capacity to act as fully autonomous persons. The lesser capacity of minors is well established in the law. As Professor Hafen observes, "it [is] of profound importance in all legal inquiries involving children that minors are presumed by all phases of the law (and by the culture reflected by our law) not to have the same basic capacities as adults." ${ }^{232}$ In this vein, Bellotti merely reiterated what the common law already understood, which is that children do not possess the same capacity to act autonomously that adults have. ${ }^{233}$

Since minors do not possess this capacity, their rights are not fundamental in the same sense that adult rights are fundamental. This is not to say that a minor's rights have no value, or, even worse, that a minor has no rights. As Judge Rogers explained in Hutchins v. District of Columbia, "234 "minors and adults share basic rights, but these rights have less force when used by minors as shields against regulation." ${ }^{, 235}$ Because the rights of minors have less force as shields against regulation, a strict scrutiny standard of review is inappropriate.

The foregoing discussion assumes that capacity is relevant to the definition and assertion of fundamental rights. A more radical approach to children's rights argues that capacity should not be relevant to the consideration of constitutional rights, and that children should be endowed with fundamental rights because they are powerless vis$\grave{a}$-vis the state. ${ }^{236}$ The view that children should be afforded fundamental rights because they are powerless vis-à-vis the state seeks to equate children with historically oppressed groups, such as women and African Americans. ${ }^{237}$

232 Bruce C. Hafen, Children's Liberation and the New Egalitarianism: Some Reservations About Abandoning Youth to Their "Rights," 1976 BYU L. REv. 605, 646-47 (1976).

233 See supra note 71 and accompanying text.

234188 F.3d 531 (D.C. Cir. 1999) (en banc).

235 Id. at 563.

236 See Katherine Hunt Federle, Children, Curfews, and the Constitution, 73 WASH. U. L.Q. 1315, 1350 (1995) (describing the empowerment rights theory, under which fundamental rights would inhere in children because of their powerlessness as to the state). This argument may be taken as an attempt to classify minors as a "discrete and insular minority" within the meaning of United States v. Carolene Products Co., 304 U.S. 144, 152-53 n.4 (1938) (suggesting that review of statutes targeted at constitutional rights of particular groups may be subjected to judicial scrutiny more exacting than the rational basis test). The Court rejected a similar argument made by senior citizens that they should enjoy status as a suspect classification because of their age. See generally Gregory v. Ashcroft, 501 U.S. 452 (1991).

237 See Federle, supra note 236, at 1340-44 (comparing the experience of children to slavery and the civil rights movement). 
The argument, for example, is that African-American slaves, like minors, were treated paternalistically by most whites. ${ }^{238}$ Slaves were viewed much like children, and thus their relationship with their owner was seen to be similar to that of child to parent. ${ }^{239}$ Looking back through the lens of history, it is clear "that the infantilization of African-Americans was nothing more than an attempt to control and oppress an entire race."240 Similarly, rights theories that do not allow for children as rights-holders perpetuate "these traditions of power and dominance." ${ }^{241}$ Thus, children must be afforded rights so that they can challenge the existing hierarchies and power structures. ${ }^{242}$

However, there are relevant differences between children and other oppressed social groups that make this analogy weak. First, the interests of the "power holders," or those institutions that perpetuate the existing hierarchies, are different. Whereas oppressors have an interest in maintaining oppression, those who preside over the lives of children have an interest in terminating the child's dependent condition. ${ }^{243}$ Thus, to the extent that the motivations of the state are a concern, there is less likelihood of an illicit motive in the case of children. ${ }^{244}$

Furthermore, and perhaps more importantly, childhood is not a permanent state. In this sense, a child's lack of power is less permanent than that of a slave. ${ }^{245}$ While a slave will always be a slave, a child will not always be a child. The slave's only remedy is to be bestowed with rights. The child has a further remedy-she may grow up. ${ }^{246}$ In this sense, childhood is not an immutable characteristic, and children thus lack one of the features that have historically qualified a

238 See id. at 1343 (arguing that even though some slave owners had sexual relations with their slaves, these owners dared not treat them as equals for fear of sacrificing control over them).

${ }^{239}$ See id. (describing the position held by many that slaves, like children, had reduced mental capacity and were thus dependent on their masters for guidance and protection).

240 Id. at 1344. The author continues to note that slaves were not seen as rights-holders, and the notion that slaves would have been able to exercise such rights was inconceivable to whites. See id.

241 Id.

${ }^{242}$ See $i d$. (arguing that the experience of African-American slaves demonstrates the impotence of rights that are incapable of challenging existing hierarchies).

${ }^{243}$ See ONORA O'NEILL, Children's Rights and Children's Lives, in CHLDREN's RIGHTS RE-VISIONED 38 (Rosalind Eckman Ladd ed. 1996).

244 See Laurence H. Tribe, Childhood, Suspect Classifications, and Conclusive Presumptions: Three Linked Riddles, 39 LAW \& CONTEMP. PROBS. 8, 10 n.8 (1975) ("No adult, having once been a child, can with real conviction draw the line between "us" and "them" - the line that makes it at least plausible in other contexts to treat "them" as a special minority needing protection from politics.").

245 See O'NeILL, supra note 243 , at 38.

246 See id. at 39. 
group as a discrete and insular minority. ${ }^{247}$ Therefore, a strict scrutiny standard of review is inappropriate.

\section{B. The Need for Something More than Rational Basis Review}

Only two courts hold that the appropriate standard of review is the rational basis test. ${ }^{248}$ Their main argument is that a minor's liberty interest is circumscribed by his or her inability to exercise the right maturely. ${ }^{249}$ Since minors are more vulnerable than adults, and because minors may commit delinquent acts due to their immaturity, the child's right to freedom of movement is not fundamental. Therefore, a rational basis standard of review is appropriate because no fundamental right is implicated. ${ }^{250}$

This argument has superficial appeal because it accurately describes the Court's two-tiered mode of analysis in due process cases. Either a regulation burdens fundamental rights and is subject to strict scrutiny, or it does not and is judged under rational basis review. In the end, however, this is not an adequate justification for evaluating statutes burdening a minor's rights under the same deferential standard that courts use when evaluating legislation that impacts economic rights. ${ }^{251}$

Clearly, children do not have substantive liberty rights in the same sense, and of the same scope, as adults. ${ }^{252}$ There is a major logic gap, however, between this premise and the conclusion that rational basis review is required. The conclusion rests on the further premise

247 Professor Federle challenges the relevance of these distinctions, commenting that "[a]ny form of oppression has negative consequences and should be intolerable in a rightsoriented society." Federle, supra note 236 , at 1344 n.198.

248 See In re J.M., 768 P.2d 219, 223 (Col. 1989); City of Panora v. Simmons, 445 N.W.2d 363, 368-69 (Iowa 1989).

${ }_{249}$ See In re J.M., 768 P.2d at 223; Simmons, 445 N.W.2d at 369 . This argument derives from the three factors enunciated by the plurality in Bellotti v. Baird, 443 U.S. 622,634 (1979). See supra note 119 and accompanying text.

${ }_{250}$ See In re J.M., 768 P.2d at 223 (concluding that a minor's "liberty interest in freedom of movement does not constitute a fundamental right" and accordingly stating that the curfew law at issue will be measured by "the rationality standard"); Simmons, 445 N.W.2d 363, 368-69 (lowa 1989) ("[A] minor's right of intracity travel is not a fundamental right for due process purposes, and the ordinance need not meet a strict scrutiny test.").

25t See Juvenile Curfews and the Constitution, supra note 217, at $1172 \mathrm{n.44}$ ("[T] he rights of children should not be subordinated to the will of the majority or limited purely for economic or efficiency reasons ....").

${ }^{252}$ See Schleifer v. City of Charlottesville, 963 F. Supp. 534, 540 (W.D. Va. 1997) ("Bending to the dictates of common sense, the Supreme Court [has] recognized that the behavior of minors may be constitutionally regulated more stringently than that of adults."); $\mathrm{Nu}$ nez v. City of San Diego, 963 F. Supp. 912, 923 (S.D. Cal. 1995), rev'd, 114 F.3d 935 (9th Cir. 1997) ("The conclusion that minors possess a lesser right to free movement than adults corresponds with society's recognition that minors are more vulnerable to society's dangers than adults and that juveniles lack the ability 'to make critical decisions in an informed mature manner."') (citation omitted); see also supra Part II (tracing judicial development of minors' rights). 
that there is no middle ground between strict scrutiny and rational basis review. True, most due process cases fit neatly into a two-tiered scheme of review. This method, however, is not set in stone. The Court has already discarded it when analyzing cases under the Equal Protection Clause. ${ }^{253}$ There is a similar need to discard the two-tiered mode of analysis when dealing with the rights of minors. As Justice Frankfurter observed, "[l]egal theories and their phrasing in other cases readily lead to fallacious reasoning if uncritically transferred to determination of a State's duty towards children." 254

Analyzing all burdens on the rights of minors under a rational basis standard of review does not respect Supreme Court precedent. ${ }^{255}$ It also fails to give minors the respect they deserve as persons possessed of rights under the Constitution ${ }^{256}$ by requiring only that legislation respecting minors is not arbitrary, a requirement that all legislation must meet anyhow. Therefore, something more than rational basis review is required.

\section{Intermediate Scrutiny: A Workable Compromise}

We are left then with the task of defining the minor's relationship vis-à-vis the state in the constitutional sense. Strict scrutiny is not appropriate, ${ }^{257}$ and neither is rational basis review. ${ }^{258}$ What is needed is an approach that recognizes the significance of a minor's diminished capacity and greater vulnerability without dehumanizing its

253 As Justice Marshall stated:

The Court apparently seeks to establish today that equal protection cases fall into one of two neat categories that dictate the appropriate standard of review-strict scrutiny or mere rationality. But this Court's decisions in the field of equal protection defy such easy categorization. A principled reading of what this Court has done reveals that it has applied a spectrum of standards in reviewing discrimination allegedly violative of the Equal Protection Clause.

San Antonio Indep. School Dist. v. Rodriguez, 411 U.S. 1, 98-99 (1973) (Marshall, J., dissenting).

What Justice Marshall intuitively recognized in 1973 is now plainly evident in the Court's jurisprudence. As Judge Michael recognized in Schleifer, "the presumption of equal treatment under the Constitution is somewhat diluted by the sliding scale of scrutiny employed by the Supreme Court, depending on the characteristics of the individual seeking constitutional protection." 963 F. Supp. at 541. For example, while the Supreme Court reaffirmed in Adarand Constructors, Inc. v. Pena, 515 U.S. 200, 238-39 (1995), that all race-based classifications are subject to strict scrutiny review, classifications that are based on gender are subject to an intermediate level of review. See generally United States v. Virginia, 518 U.S. 515 (1996).

254 May v. Anderson, 345 U.S. 528, 536 (1953) (Frankfurter, J., concurring).

255 See supra Part II (canvassing Supreme Court development of juvenile rights).

256 The Supreme Court has stated that "[c]onstitutional rights do not mature and come into being magically only when one attains the state-defined age of majority. Minors, as well as adults, are protected by the Constitution and possess constitutional rights." Planned Parenthood v. Danforth, 428 U.S. 52, 74 (1976) (citations omitted).

257 See supra Part III.A.

258 See supra Part III.B. 
subject-an approach that is both internally coherent, and not so foreign to the field of constitutional law that it is rendered impossible to apply. As federal courts have increasingly come to recognize, ${ }^{259}$ the proper standard of review in cases involving juvenile rights is intermediate scrutiny. ${ }^{260}$

An intermediate standard of review finds support in two of the court's opinions in cases dealing with abortion rights. First in Planned Parenthood v. Danforth, ${ }^{261}$ and then again in Carey v. Population Services International, ${ }^{262}$ the court flirted with an intermediate standard of review. In Danforth, the Court reviewed, inter alia, the constitutionality of a portion of the abortion legislation passed by Missouri that pertained to juveniles. ${ }^{263}$ The Court stated that the question

259 Several courts have applied an intermediate standard of scrutiny to juvenile rights. See, e.g., Hutchins v. District of Columbia, 188 F.3d 531 (D.C. Cir. 1999) (en banc); Schleifer v. City of Charlottesville, 963 F. Supp. 534, 542 (W.D. Va. 1997); see also Peter L. Scherr, Note, The Juvenile Curfew Ordinance: In Search of a New Standard of Review, 41 WASH. U. J. URB. \& CONTEMP. L. 163, 191 (1992) (advocating a form of intermediate scrutiny to be applied to evaluation of juvenile rights).

${ }^{260}$ The test that I am proposing is confined to purported infringements upon the substantive liberty interests of minors. Therefore, this test would not apply in determining the procedural rights of minors in the juvenile court system. See generally Breed v. Jones, 421 U.S. 519 (1975) (holding the Fifth Amendment's double jeopardy clause applicable to minors in juvenile court proceedings); McKeiver v. Pennsylvania, 403 U.S. 528 (1971) (holding that the Sixth Amendment right to trial by jury does not apply to minors in juvenile court proceedings); In re Winship, 397 U.S. 358 (1970) (holding that juveniles in a juvenile court proceeding are entitled to the protection of the proof beyond a reasonable doubt standard); In re Gault, 387 U.S. 1 (1967) (holding the constitutional rights of notice to charges, counsel, confrontation, and crossexamination, and privilege against self-incrimination applicable to juveniles in juvenile court proceedings).

Likewise, the First Amendment may present a special case. At least in the context of schools, there is greater reason to treat the First Amendment rights of juveniles as analogous to those of adults. The First Amendment encompasses a societal right to information in the form of ideas. As Justice Brandeis has stated:

[The founding fathers] believed that freedom to think as you will and to speak as you think are means indispensable to the discovery and "spread of political truth; that without free speech and assembly discussion would be futile; that with them, discussion affords ordinarily adequate protection against the dissemination of noxious doctrine; that the greatest menace to freedom is an inert people; that public discussion is a political duty; and that this should be a fundamental principle of the American government.

Whitney v. California, 274 U.S. 357, 375 (1927) (Brandeis, J., concurring) (footnote omitted). As has been recognized by the Court, "[t] Tinker v. Des Moines Independent Community School District, 393 U.S. 503, 512 (1969) (quoting Keyishian v. Bd. of Regents, 385 U.S. 589, 603 (1967)). Since the interest recognized here is societal and not individual, a full exploration of the issue of First Amendment juvenile rights is beyond the scope of this Note.

261428 U.S. 52 (1976).

262431 U.S. 678 (1977).

263 See Danforth, 428 U.S. at 72-75. The applicable section of the Missouri statute required that during the first 12 weeks of her pregnancy the minor must obtain the written consent of one parent or person in loco parentis of the woman if the woman was unmarried and under the age of eighteen years, unless the abortion is certified by a licensed physician as necessary in order to preserve the life of the mother. See id. at 58. The court held that "the State does not have the 
was "whether there is any significant state interest ... that is not present in the case of an adult."264 A four-justice plurality applied the same standard in Carey, ${ }^{265}$ observing that "[t]his test is apparently less rigorous than the 'compelling state interest' test applied to restrictions on the privacy rights of adults." ${ }^{266}$ The plurality felt that this lesser degree of scrutiny was appropriate, both because of the greater degree of latitude that the states have when regulating the conduct of minors, and because the law presumes that minors have a lesser capacity "for making important decisions."267 In each of these cases, the Court felt the asserted interest was insignificant, and therefore did not comment on how close the fit between the classification and the statute's purpose would have to be to satisfy the test. However, courts should require that the classification be "substantially related" to the statute's objectives. ${ }^{268}$

The requirement of a "significant," or important, governmental objective assures that minors will not be the subject of dehumanizing legislation. ${ }^{269}$ The primary concern in reviewing legislation affecting juvenile rights, ${ }^{270}$ which may be termed quasi-fundamental, should be in assuring that the legislation was drafted out of genuine concern for, and in furtherance of, a legislative purpose that is designed to protect

constitutional authority to give a third party an absolute, and possibly arbitrary, veto over the decision of the physician and his patient to terminate the patient's pregnancy." Id. at 74. The court found that an asserted state interest in safeguarding the family unity and parental authority was insufficient. See id. at 75.

254 Id. at 75 .

265 See Carey, 431 U.S. at 691-99. The issue was the constitutionality of a nonprescription contraception distribution ban pertaining to all minors under the age of 16. See id. at 691-92. New York asserted an interest in discouraging sexual activity amongst the young. See id. at 694 . The Court, however, did not take this interest seriously. See id. at 694-96. The Court, for example, found that "the State's interests in protection of the mental and physical health of the pregnant minor, and in protection of potential life are clearly more implicated by the abortion decision than by the decision to use a nonhazardous contraceptive," id. at 694 , and that "there is substantial reason for doubt whether limiting access to contraceptives will [as the State contends], substantially discourage early sexual behavior." Id. at 695 .

260 Id. at 693 n. 15 .

267 Id.

268 The requirement of a "substantial relationship between the means chosen and the end asserted is one of the hallmarks of an intermediate standard of review." See L. TRIBE, AMERICAN CONSTITUTIONAL LAW \$16-32 (2d ed. 1988).

${ }^{269}$ As Professor Tribe explains, more generally, it has become "obvious . . . that, as the Court's assessment of the weight and value of the individual interest escalates, the less likely it is that mere administrative convenience and avoidance of hearings or investigations will be sufficient to justify what otherwise would appear to be irrational discriminations." Id. $\$ 16-32$.

270 I use the term juvenile rights here to refer to rights held by juveniles, which would be fundamental if held by adults. For lack of a better term, it is perhaps appropriate to refer to these rights of juveniles as quasi-fundamental rights. Cf. Plyler v. Doe, 457 U.S. 202, 244 (1982) (Burger, C.J., dissenting) (criticizing the Court's apparent recognition of public education as a quasi-fundamental right). 
children. ${ }^{271}$ The reason for this heightened standard of review, which is less than strict scrutiny but more rigorous than rational basis, lies in the recognition that children are persons under the constitution with rights ${ }^{272}$ but they are uniquely vulnerable and not always able to exercise their rights responsibly. ${ }^{273}$

Therefore, courts should evaluate alleged infringements of juvenile rights under an intermediate standard of review. The recognition of juvenile rights as quasi-fundamental suggests that they have value and are worthy of respect. However, it also signifies the uniqueness of the rights that juveniles possess and an understanding that their rights are not as full in scope as the rights of their adult counterparts. Furthermore, the requirement that a state demonstrate an important governmental interest explicitly recognizes the greater authority of the state to regulate juvenile rights.

The most important difference between this test and either strict scrutiny or the proposed "compelling for children" test lies in the fact that an intermediate standard allows for legislation as long as it is "substantially related" to the legislative goals. Strict scrutiny is usually fatal in fact. ${ }^{274}$ While the inability of legislation to survive such review may be attributed in large part to the "compelling state interest" prong of the test, it is clear that the "least drastic means" element is important as well. ${ }^{275}$ Thus, the greater latitude in means used that is afforded by this intermediate test is crucial if the Court is to fulfill its promise that "the power of the state to control the conduct of children reaches beyond the scope of its authority over adults."276

271 As Professor Tribe explains, "[t]he "establishment of prompt efficacious procedures to achieve legitimate state ends is a proper state interest worthy of cognizance in constitutional adjudication. But the Constitution recognizes higher values than speed and efficiency." TRIBE, supra note 268 , \$16-32 (citing Vlandis v. Kline, 412 U.S. 441, 458-459 (1973) (White, J., concurring)).

${ }^{272}$ As the Danforth Court explained, "[c]onstitutional rights do not mature and come into being magically only when one attains the state-defined age of majority. Minors, as well as aduits, are protected by the Constitution and possess constitutional rights." 428 U.S. 52,74 (1976).

${ }^{273}$ See Bellotti v. Baird, 443 U.S. 622, 634 (1979) (referring to the unique characteristics of children which justify special treatment including, inter alia, "the peculiar vulnerability of children" and a child's "inability to make critical decisions in an informed, mature manner").

274 See TRIBE, supra note 268, \$ 16-6 ("When expressed as a standard for judicial review, strict scrutiny is ... 'strict' in theory and usually 'fatal' in fact.") (footnote omitted).

275 As one commentator explains, "[s]ome may argue that the 'less drastic means' element is not required in most cases. However, a close examination of the Court's analysis shows persistent consideration has been given to this element. The strict scrutiny standard has been almost impossible for lawmaking bodies to meet." Randall Fox, Equal Protection Analysis: Laurence Tribe, The Middle Tier, and the Role of the Court, 14 U.S.F. L. REV. 525,526 n.4 (1980).

276 Prince v. Massachusetts, 321 U.S. 158, 170 (1944). 


\section{JUVENILE RIGHTS AND CURFEW ORDINANCES}

"The spontaneity of children in responding to invitation to play, without calculating the risk, is as well known as the sequence of the seasons or the regularity with which night follows day. It is not an imponderable, or a matter of speculation. It is simply fact."277

This Part of the Note applies the tests derived in Parts III and IV to juvenile curfew laws. These laws directly burden a minor's right to travel on public fora, and are subject to a heightened standard of review. Because the rights of minors are lesser in scope than those of adults, however, an intermediate standard of review is applied.

Following hearings, the District of Columbia Council unanimously adopted the Juvenile Curfew Act of $1995 .^{278}$ The curfew bans

27 Jennings v. Glen Alden Coal Co., 87 A.2d 206, 212 (Pa. 1952) (Musmanno, J., dissenting).

273 The text of the curfew law is set forth in an appendix to the District Court opinion. See Hutchins v. District of Columbia, 942 F. Supp. 665, app. A at 681-82 (D.D.C. 1996), rev'd on reh'g en banc, 188 F.3d 531 (D.C. Cir. 1999). In pertinent part, the curfew ordinance reads:

$\S 6-2182$ Definitions

For the purposes of this act, the term:

(1) "Curfew hours" means from 11:00 p.m. on any Sunday, Monday, Tuesday, Wednesday, or Thursday, until 6:00 a.m. on the following day, and from 12:01 a.m. until 6:00 a.m. on any Saturday or Sunday. During the months of July and August, the term "curfew hours" means from 12:01 a.m. until 6:00 a.m.

(2) "Emergency" means an unforeseen combination of circumstances or the resulting state that calls for immediate action. The term "emergency" includes, but is not limited to, a fire, a natural disaster, an automobile accident, or any situation that requires immediate action to prevent serious bodily injury or loss of life.

(3) "Establishment" means any privately-owned place of business operated for profit to which the public is invited, including, but not limited to, any place of amusement or entertainment.

(4) "Guardian" means a person who, under court order, is the guardian of the person of a minor or a public or private agency with whom a minor has been placed by the court.

(5) "Minor" means any person under the age of 17 years, but does not include a judicially emancipated minor or a married minor.

(6) "Narcotic trafficking" means an act of engaging in any prohibited activity related to narcotic drugs or controlled substances as defined in the District of Columbia Uniform Controlled Substances Act of 1981 ....

(7) "Operator" means any individual, firm, association, partnership, or corporation that operates, manages, or conducts any establishment. The term "operator" includes the members or partners of an association or partnership and the officers of a corporation.

(8) "Parent" means a natural parent, adoptive parent or step-parent, or any person who has legal custody by court order or marriage, or any person not less than 21 years of age who is authorized by the natural parent, adoptive parent, step-parent, or custodial parent of a child to be a caretaker for the child.

(9) "Public place" means any place to which the public, or a substantial group of the public, has access, and includes, but is not limited to, streets, highways, and the 
minors under the age of 17 from being in a public place without a parent, or adult supervision, during certain hours. These hours include 11:00 p.m. - 6:00 a.m. from Sunday night through Thursday morning, and from midnight to 6:00 a.m. Saturday and Sunday. The curfew law does not include minors who are "judicially emancipated" or married. $^{279}$

\section{A. Is the Right to Travel Unduly Burdened?}

In Hutchins $v$. District of Columbia, ${ }^{280}$ the District of Columbia asserted that the ordinance furthered important interests in the reduction of juvenile crime and victimization. ${ }^{281}$ The government could argue that this regulation does not directly target a minor's interest in traveling on public fora. Rather, the ordinance is attempting to reduce

common areas of schools, hospitals, apartment houses, office buildings, transport facilities, and shops.

(10) "Remain" means to linger or stay or fail to leave the premises when requested to do so by a police officer or owner, operator, or other person in control of the premises.

(11) "Serious bodily injury" means bodily injury that creates a substantial risk of death or that causes death, serious permanent disfigurement, or protracted loss or impairment of any bodily member or organ.

§6-2183 Curfew authority; defenses; enforcement and penalties.

(a)(1) A minor commits an offense if he or she remains in any public place or on the premises of any establishment within the District of Columbia during curfew hours.

$\cdots$

(b)(1) It is a defense to prosecution under this act that the minor was:

(A) Accompanied by the minor's parent or guardian;

(B) On an errand at the direction of the minor's parent or guardian, without any detour or stop;

(C) In a motor vehicle, train, or bus involved in interstate travel;

(D) Engaged in an employment activity pursuant to [the District of Columbia child employment act], or going to, or returning home from, an employment activity, without detour or stop;

(E) Involved in an emergency;

(F) On the sidewalk that abuts the minor's residence or that abuts the residence of a next-door neighbor if the neighbor did not complain to the Metropolitan Police Department about the minor's presence;

(G) In attendance at an official school, religious, or other recreational activity sponsored by the District of Columbia, a civic organization, or another similar entity that takes responsibility for a minor, or going to, or returning home from, without any detour or stop, an official school, religious, or other recreational activity supervised by adults and sponsored by the District of Columbia, a civic organization, or another similar activity that takes responsibility for a minor; or

(H) Exercising First Amendment rights protected by the United States Constitution, including free exercise of religion, freedom of speech, and the right of assembly ....

D.C. CODE ANN. $\$ \S 6-2182,2183$ (Supp. 1999).

279 See supra note 278.

280188 F.3d 531 (D.C. Cir. 1999) (en banc).

281 See id. at 541-42. 
juvenile crime and victimization. Thus, the ordinance impacts upon the minor's right to travel on public fora only indirectly.

The problem with this argument is that it proves too much. Such an argument would almost always convert direct regulations into incidental burdens because "what renders the exercise of a right offensive to the majority has little to do with what renders the right valuable to the rightholder."282 In other words, "it is usually possible to characterize the harm that a right's exercise causes in a way that does not target the right's value from the perspective of the rightholder."283

Here, the burden is not incidental in the usual sense because it applies only to conduct that is protected. The ordinance, while being concerned with juvenile crime and victimization, does not punish or seek to regulate any conduct associated with these two goals other than a minor's right to travel. The burden is thus direct in the sense that the means the legislature used to further its goals were solely concerned with restricting a minor's right to travel. Hence, the regulation is targeted to prevent a minor's exercise of the right to travel. As Judge Rogers observed, "[w]hatever else the curfew might be, it is not an incidental burden. The curfew . . . does not constrain specific types of movement, but with few exceptions bars all movement in public; it is not confined to a brief period, but extends for roughly $25 \%$ of the day. ${ }^{284}$ Therefore, the curfew law is subjected to heightened scrutiny because it imposes a "substantial obstacle" on a minor's right to travel.

\section{B. Curfew Laws and Intermediate Scrutiny}

In order to pass the intermediate level of scrutiny applicable to an alleged infringement of a minor's quasi-fundamental right, the District of Columbia curfew law must be substantially related to significant state interests. ${ }^{285}$

\section{Significant State Interests}

The District of Columbia's interest in enacting its curfew law was "to protect the welfare of minors by reducing the likelihood that minors will perpetrate or become victims of crime and by promoting

282 Dorf, supra note 205, at 1222.

283 Id. at 1223.

284 Hutchins, 188 F.3d at 562 (Rogers, J., concurring in part and dissenting in part).

${ }^{235}$ See Lalli v. Lalli, 439 U.S. 259 , 265 (1978) (framing the intermediate scrutiny standard as whether the legislative classification is "substantially related to permissible state interests"); see also supra note 268 and accompanying text. 
parental responsibility." 2866 There should be no doubt that these interests are substantial.

The Court has long recognized that a state's interest in the wellbeing of its youth is compelling. In New York v. Ferber, ${ }^{287}$ the Court stated that "a State's interest in 'safeguarding the physical and psychological well-being of a minor' is 'compelling." "288 In Ginsburg $v$. New York, ${ }^{289}$ the Court recognized that society has an interest in assuring that children are "'safeguarded from abuses' which might prevent their "growth into free and independent well-developed men and citizens." ${ }^{290}$ This interest exists "even when the laws have operated in the sensitive area of constitutionally protected rights. ${ }^{291}$

Several lower courts have questioned whether a state or local government has an interest in enacting a curfew law that is "compelling for children." ${ }^{292}$ The argument is that the state does not have an interest that is compelling for children because a minor is not "peculiarly vulnerable" to night-time crime, and "the decision to go outside during certain hours does not involve any critical decisions by minors. ${ }^{293}$ As set forth above, ${ }^{294}$ this approach is conceptually misguided because it equates a minor's capacity with the state's interest instead of with the scope of the minor's right. However, the argument also rests on a fundamental misunderstanding of precedent.

The decisions that hold that the state or local government does not have an interest in enacting a curfew law that is "compelling for children" rely on the three factors set forth in Bellotti v. Baird. ${ }^{295}$

The Bellotti plurality stated that "the Court has held that the States validly may limit the freedom of children to choose for themselves in the making of important, affirmative choices with potentially serious consequences. ${ }^{2296}$ Interpreting this portion of Bellotti to

286 Hutchins, 188 F.3d at 541-42 (quoting Globe Newspaper Co. v. Superior Court, 457 U.S. 596, 607 (1982)).

287458 U.S. 747 (1982).

288 Id. at $756-57$.

289390 U.S. 629 (1968).

290 Id. at 640-41 (quoting Prince v. Massachusetts, 321 U.S. 158, 165 (1944)).

291 Ferber, 458 U.S. at 757.

292 See, e.g., Waters v. Berry, 711 F. Supp. 1125, 1137 (D.D.C. 1989) (holding that the danger of nighttime violence is not peculiar to children and curfews may infringe on parental choice); Brown v. Ashton, 611 A.2d 599, 608-09 (Md. App. 1992). But see Nunez v. City of San Diego, 114 F.3d 935, 947 (9th Cir. 1997) (recognizing "that minors are more susceptible to the dangers of the night and are generally less equipped to deal with danger that does arise").

293 Brown v. Ashton, 611 A.2d 599, 609 (Md. App. 1992). rights).

294 See supra Part IV (advocating the intermediate scrutiny standard for review of juvenile 295443 U.S. 622 (1979). For a discussion of Bellotti, see supra notes 224-26 and accompanying text.

296 Id. at 635. 
require that the decision be a "critical" one $e^{297}$ is simply wrong. How important must these choices be? In the next sentence, the Bellotti plurality explains that "minors often lack the experience, perspective, and judgment to ... avoid choices that could be detrimental to them."298

In explaining what "choices that could be detrimental" means, the Bellotti plurality relied exclusively on the case of Ginsberg $v$. New York. ${ }^{299}$ Ginsberg involved a minor's asserted right to choose whether to buy "so-called 'girlie' magazines." ${ }^{300}$ The Court did not require proof that the purchase of these magazines could be detrimental. Rather, it was enough for the Court that "the growing consensus of commentators is that "while these studies all agree that a causal link has not been demonstrated, they are equally agreed that a causal link has not been disproved either." ${ }^{301}$ Hence, choices that are "important," or "could be detrimental," are choices that a rational person believes could harm a child, if there is no solid proof to the contrary. With respect to curfew laws, the Ninth Circuit's observation is on point: "[I] [is] unexceptional for the City to conclude that minors are more susceptible to the dangers of the night and are generally less equipped to deal with danger that does arise."302

In sum, it is clear that a government has a significant interest in safeguarding the welfare of minors. This interest is present where the government enacts a curfew law, and nothing in Bellotti should be construed to the contrary. These curfew laws are constitutional when challenged on right to travel grounds if they are "substantially related" to this interest. ${ }^{303}$

\section{Curfew Laws and the "Substantial Relation" Requirement}

The substantial relation requirement does not require mathematical precision. "In the end, the precise accuracy of [the State's] calculations is not a matter of specialized judicial competence; and [courts] have no basis to question their detail beyond the evident consistency and substantiality." 304 The Court has emphasized that, "[i]t is unrealistic to expect either members of the judiciary or state officials to be well versed in the rigors of experimental or statistical technique."305

297 Brown, 611 A.2d at 609.

Bellotti, 443 U.S. at 635 (footnote omitted).

2wi See id. at 636 (citing Ginsberg v. New York, 390 U.S. 629 (1968)).

300 Ginsberg, 390 U.S. at 631.

301 Id. at 642 (citations omitted).

302 Nunez v. City of San Diego, 114 F.3d 935, 947 (9th Cir. 1997).

303 See supra note 285 and accompanying text.

304 Lalli v. Lalli, 439 U.S. 259, 274 (1978).

305 Craig v. Boren, 429 U.S. 190, 204 (1976). 
What is required is a fit between the governmental interests and the means chosen that is not unduly tenuous. ${ }^{306}$ However, such a relationship does have to be empirical. ${ }^{307}$

The District of Columbia was confronted with evidence of an ever-increasing juvenile crime rate. ${ }^{308}$ The evidence before the District Court included statistics, which stated that in 1992 the D.C. crime arrest rate for youths aged ten to seventeen was the highest in the nation. ${ }^{309}$ D.C. also "had the highest violent death rate [in the nation] for teens ages 15 to $19 \ldots, 310$ The D.C. Council also had before it statistics that showed a high number of incidents of violent crime in areas covered by the curfew. ${ }^{311}$

The D.C. Council reviewed evidence relating to the efficacy of juvenile curfew laws in other jurisdictions, which showed that after a juvenile curfew was enacted the number of juvenile arrests for violent offenses decreased. ${ }^{312}$ A couple of jurisdictions had also experienced a reduction in juvenile victimization. ${ }^{313}$ The Council heard evidence that "more than $50 \%$ of juvenile arrests took place during curfew hours." "314 The D.C. Council also utilized a statistical projection from the police chief on the anticipated effect of a curfew statute. ${ }^{315}$

306 See Lalli, 439 U.S. at 273 (stating that a court's constitutional inquiry into a state law "does not focus on the abstract "faimess" of a state law, but on whether the statute's relation to the state interests it is intended to promote is so tenuous that it lacks the rationality contemplated by the Fourteenth Amendment"). As the Fifth Circuit has explained:

We will not ... . insist upon detailed studies of the precise severity, nature, and characteristics of the juvenile crime problem in analyzing whether the [curfew law] meets constitutional muster .... . Federal courts have always been reluctant to question the potential effectiveness of legislative remedies designed to address societal problems.

Qutb v. Strauss, 11 F.3d 488, 493 n. 7 (5th Cir. 1993).

307 See Lalli, 439 U.S. at 274.

308 See Hutchins v. District of Columbia, 188 F.3d 531, 542 (D.C. Cir. 1999) (en banc).

309 See id. This rate was more than three times the national average. See id.

310 Id.

311 See Hutchins v. District of Columbia, 144 F.3d 798, 810 (D.C. Cir. 1998), rev'd on reh'g en banc, 188 F.3d 531 (D.C. Cir. 1999). The court continued:

Further, elected representatives of Advisory Neighborhood Commissions ("ANCs") and other District residents testified before the D.C. Council about violence plaguing the streets, gunfire from early evening through early moming, children counting the new bullet holes every morning in the doors to their kindergartens, the worsening of teen violence, the gang victimization of youths, and murder becoming sport. Id. at 810-11.

${ }^{312}$ See Hutchins v. District of Columbia, 942 F. Supp. 665, 675 n.13, rev'd on reh'g en banc, 188 F.3d 531 (D.C. Cir. 1999) (stating that statistics from Dallas showed that the city recorded a $21.7 \%$ decrease in juvenile arrests for violent crimes); Hutchins, 144 F.3d at 812 (noting similar studies in New Orleans and San Antonio).

313 See Hutchins, 942 F. Supp. at 675 n.13 (noting that statistics from San Antonio showed a $60 \%$ decrease in juvenile victimization during curfew hours).

314 Hutchins, 188 F.3d at 544.

315 See Hutchins, 144 F.3d at 812. The Police Chief informed the D.C. Council, after the curfew law had been in effect for three months, "that ' $[t]$ he juvenile curfew has made a signifi- 
The "substantial relation" requirement is satisfied by such a showing. Experiences of other cities with curfew laws are an important source of information that should not be disregarded "so long as whatever evidence the city relies upon is reasonably believed to be relevant to the problem that the city addresses." ${ }^{316}$ As Judge Silberman, writing for the plurality in Hutchins, remarked, "it would be folly for any city not to look at experiences of other cities."317

The fact that some of the statistics used by the Council included 17-year-olds, who were not subject to the curfew, does not make the "fit" insubstantial. As the Supreme Court has explained, "[t]he "precise accuracy of [the State's] calculations is not a matter of specialized judicial competence." ${ }^{318}$ Additionally, "few statutory classifications'are entirely free from the criticism that they sometimes produce inequitable results." ${ }^{, 319}$ Crime deterrence is not the sole concern of those who pass a curfew law. The legislature also must consider the average maturity of the age group whose rights it inhibits.

Therefore, while it may well be that juveniles who are age seventeen commit a significant portion of juvenile crimes, the fact that this group of juveniles is excluded from the ordinance does not make the means insubstantially related to the ends of the curfew law. The presumably higher degree of maturity possessed by seventeen yearolds $^{320}$ justifies their exclusion from the curfew law. ${ }^{321}$ The precise accuracy of this legislative determination is not a matter of "specialized judicial competence."

The fact that the Council was unable to discern the precise number of juvenile crimes that took place during curfew hours is also not determinative. The Council was presented with evidence that "more than $50 \%$ of juvenile arrests took place during curfew hours., ${ }^{, 322}$ Under similar circumstances, the Fifth Circuit stated that "[a]lthough the city was unable to provide precise data concerning the number of juveniles who commit crimes during the curfew hours, or the number of

cant impact on the District's youth arrest rate,' noting a decrease of $39 \%$ in the arrest rate for more serious offenses and a 34\% decrease over all." Id. at 814 n.28.

${ }_{316}$ City of Renton v. Playtime Theaters, Inc., 475 U.S. 41, 51-52 (1986).

317 Hutchins, 188 F.3d at 544.

318 Lalli v. Lalli, 439 U.S. 259, 274 (1978) (quoting Matthews v. Lucas, 427 U.S. 495, 515 (1976).

319. Id. at 273.

320 17 year-olds, after all, are only one year removed from exercising the right to vote. See U.S. CONST. amend. XXVI.

32t The discussion in Part IV, supra, demonstrates that what justifies the differential treatment of minors is their comparative lack of capacity. When precisely this lack of capacity ends, or ceases to become determinative where it is still relevant, is a question without a clear answer. It is, however, a determination that should be made by the parents of the community through their council members, rather than by unelected federal judges.

${ }_{322}$ Hutchins v. District of Columbia, 188 F.3d 531, 544 (D.C. Cir. 1999) (en banc). 
juvenile victims of crimes committed during the curfew, the city nonetheless provided sufficient data to demonstrate that the classification created by the ordinance "fits." ${ }^{323}$ Because there is a sufficient fit between the means used by the District of Columbia and the goal of protecting juveniles from crime and victimization, the curfew is constitutional.

\section{CONCLUSION}

More than eighty years ago, Justice Brandeis looked upon our system of government and remarked that "one of the happy incidents of the federal system [is] that a single courageous State may, if its citizens choose, serve as a laboratory; and try novel social and economic experiments without risk to the rest of the country.,"324 The nation has been experimenting with the efficacy of curfew laws for the past ten years. Courts should not step in and stop this experiment. While a right to travel on public fora exists, the rights of minors have always been subject to certain burdens that a state could not place on the rights of adults. Unless cities panic and pass curfew laws without justification, these laws should survive constitutional scrutiny because they are substantially related to the significant government interest of protecting juveniles from crime.

BENJAMIN C. SASSE ${ }^{\dagger}$

323 Qutb v. Strauss, 11 F.3d 488, 493-94 (5th Cir. 1993).

324 New State Ice Co. v. Liebmann, 285 U.S. 262, 311 (1932) (Brandeis, J., dissenting).

+ With thanks to Professor Jonathan Entin for suggesting the topic, to Professor Ken Margolis for reviewing earlier drafts of this Note, and Cynthia Sassé for her helpful editorial suggestions. 